\title{
A Christian Emperor between Pagan Gods
}

\section{The Late-Antique Fate of the 'Temple of Hadrian' at Ephesus and Possible Approaches to Contested Monuments}

\author{
Ketty Iannantuono | ORCID: 0000-0002-0368-0553 \\ PhD Candidate, Radboud Institute for Culture \& History, Radboud \\ Universiteit, Nijmegen, The Netherlands \\ ketty.iannantuono@ru.nl
}

Received January 2021 | Accepted July 2021 |

Published online October 18, 2021

\begin{abstract}
In recent years, images of rage against monuments have filled the media. Unmistakably expressing a high degree of tension in societies, these forms of hostility against heritage have been diversely interpreted, prompting passionate expressions of support as well as fierce criticism. Contesting public memorials, however, is not a new form of socio-political dissent. During Late Antiquity, for example, a new sensibility towards ancient monuments emerged in the vast territories that were once part of the Roman Empire. In this article, the late-antique fate of the so-called 'temple of Hadrian' at Ephesus is analysed as a case-study. The aim is to gain a better understanding of the approaches adopted to accommodate traditional monumental landscapes in the changed late-antique socio-political context. This analysis offers a new perspective on ancient and contemporary phenomena of contestations of monuments.
\end{abstract}

\section{Keywords}

contested monuments - heritage - cultural appropriation - Late Antiquity late-antique Ephesus - Theodosian monumentality 
In recent years, images of rage against statues and monuments have filled the media. Numerous protests have been characterised by the targeting of public memorials as embodied testimonies of long-lasting socio-political injustice. The damaging of confederate monuments in the United States and the tearing down of imperialists' statues in Britain by the anti-racism Black Lives Matter movement, the contestation of colonial memorials in South Africa and Britain by the activists of the Rhodes must fall campaign, the purging of Lenin's memorials from public squares all across East Europe, the toppling of statues of former dictators like Saddam Hussein in Iraq, Hafaz Al-Assad in Syria, Muammar el-Qaddafi in Libya and Chiang Kai-shek in Taiwan, are just some of the latest examples. This phenomenon has confronted academics and society at large with contemporary practices of commemoration. ${ }^{1}$ Unmistakably expressing a high degree of social tensions, hostilities against monuments have been diversely interpreted, prompting passionate expressions of support as well as fierce criticisms and inflaming debate on best practice in the management

1 See e.g. S. Marshall, “Targeting Statues: Monument 'Vandalism' as an Expression of Sociopolitical Protest in South Africa." African Studies Review (6o) (3) (2017), 203-219; J. Osborne, "Counter-monumentality and the vulnerability of memory." Journal of Social Archaeology (17) (2) (2017), 163-187; J. Burch-Brown, "Is it wrong to topple statues and rename schools?" Journal of Political Theory and Philosophy (1) (1) (2017), 68-69; M. Auslander, "Putting them in museums? Reimagining the path forward." Museum Anthropology (41) (2) (2018), 137-139; D. Demetriou and A. Wingo, "The ethics of racist monuments." In Palgrave Handbook of Philosophy and Public Policy, ed. D. Boonin (Bolder: Palgrave Macmillan, 2018), 341-356; H. Frowe, "The duty to remove statues of wrongdoers." Journal of Practical Ethics (7) (3) (2019), 1-31; T.H. Lai, "Political vandalism as counter-speech: A defense of defacing and destroying tainted monuments." European Journal of Philosophy (23) (3) (2019), 6o2-616; J. Schulz, "Must Rhodes Fall? The Significance of Commemoration in the Struggle for Relations of Respect." Journal of Political Philosophy (27) (2) (2019), 1-21; V. Apaydin, "Heritage, memory and social justice: reclaiming space and identity." In Critical Perspectives on Cultural Memory and Heritage. Construction, Transformation and Destruction, ed. V. Apaydin (London: UCL Press, 2020), pp. 84-97; A. Bauer, "Itineraries, iconoclasm, and the pragmatics of heritage." Journal of Social Archaeology (o) (2020), 1-25; C. Baxter, "Statues aren't our history. They're our archaeology." Medium, June 20, 2020; M. Beard, "Statue wars." The Times Literary Supplement, June 11, 2020; M. Dickinson, "Black realities and white statues: The fall of Confederate monuments. Black Perspectives." African American Intellectual History Society, June 18, 2020; S. Frank and M. Ristic, eds., Urban Heritage in Divided Cities. Contested Pasts (London-New York: Routledge, 2020); C.M. Lim, "Vandalizing tainted commemorations." Philosophy \& Public Affairs (48) (2) (2020), 185-216; T. Timmerman, "A case for removing Confederate monuments." In Ethics Left and Right: The Moral Issues that Divide Us, ed. B. Fischer (Oxford-New York: Oxford University Press, 2020), 513-522. 
of 'contested cultural heritage.' The approaches most frequently suggested entail either the purge of public memoryscapes of unsolicited components, or the protection and the valorisation of contested monuments. These methods can be broadly grouped in three macro categories, namely removing, preserving and recontextualising. ${ }^{3}$ Each option offers practical solutions, and yet at the same time they are overshadowed by problematic aspects. Yet, the assessment of the potential strengths and weaknesses of these practices is often troubled by moralistic concerns. Consequently, the evaluation of the best approaches for the management of public monuments is not always conducted on the basis of lucid reflections and can be biased.

One way of gaining detachment from ethical issues and contested practices is to adopt an historical perspective. ${ }^{4}$ Contesting public memorials is not

2 The definition of 'cultural heritage' has spurred scholarly debate in recent years. Adopting a constructionist perspective, recent literature has highlighted that 'heritage' is not much bound to the specific ancient artefacts, landscapes, memories and practices now recognised as 'heritage-resources'. Instead, heritage appears to be heavily dependent on the meanings, interpretations and representations placed upon these 'resources' in the present. See e.g. D. Lowenthal, "Introduction." In Possessed by the Past: The Heritage Crusade and the Spoils of History, ed. D. Lowenthal (Cambridge: Cambridge University Press, 1998), xiii-xvii; R.S. Peckham, "Introduction: The Politics of Heritage and the Public Culture." In R.S. Peckham (ed.), Rethinking Heritage: Cultures and Politics in Europe (London: I.B. Tauris, 2003), 1-13; Y. Hamilakis, "Memories Cast in Marble: Introduction." In The Nation and Its Ruins: Antiquity, Archaeology, and National Imagination in Greece, ed. Y. Hamilakis (Oxford: Oxford University Press, 2007), 1-33; D. Harvey, "The History of Heritage." In The Ashgate Research Companion to Heritage and Identity, eds. B. Graham, P. Howard (London-New York: Routledge, 2008), 19-36. For definitions of 'cultural heritage' as, 'dissonant', 'difficult', and 'dark', see e.g. J. Tunbridge and G. Ashworth, Dissonant Heritage: The Management of the Past as a Resource in Conflict (Chichester: John Wiley, 1996); S. Macdonald, Difficult Heritage: Negotiating the Nazi Past in Nuremberg and Beyond (London: Routledge, 2009); W. Logan and K. Reeves, Places of Pain and Shame: Dealing with "Difficult Heritage." (London: Routledge, 2009); D.J. Timothy and G.P. Nyaupane, "The politics of heritage." In Cultural heritage and tourism in the developing world: a regional perspective, eds. D.J. Timothy and G.P. Nyaupane (London: Routledge, 2009), 42-44; C. Roberts and P.R. Stone, "Dark Tourism and Dark Heritage: Emergent Themes, Issues and Consequences." In Displaced Heritage: Responses to Disaster, Trauma and Loss, eds. I. Convery, G. Corsane and P. Davis (Woodbridge: Boydell and Brewer, 2014), 9-18. For an updated overview on the approaches to the study of 'contested' heritage, see E. Solomon, "Introduction: Contested Antiquity in Greece and Cyprus." In Contested Antiquity. Archaeological Heritage and Social Conflict in Modern Greece and Cyprus, ed. E. Solomon (Bloomington: Indiana University Press, 2021), 1-49. Cf. infra note 4 for the discussion about the opportune use of the concept of 'heritage' to describe ancient phenomena.

3 J. Burch-Brown, "Should Slavery's Statues Be Preserved? On Transitional Justice and Contested Heritage." Journal of Applied Philosophy, Special Issue (2020), 1.

4 Recent research has underlined the difficulties in applying the concept of 'heritage' tout court to the phenomena observable in the ancient world. See e.g. C. Siwicki, Architectural Restora- 
at all a new form of socio-political dissent. On the contrary, in diverse historical settings, social groups that challenged their contemporary status quo have recurrently targeted monuments as signposts of distrusted ideologies and systems of values. ${ }^{5}$ For instance, a wide range of practices of damnatio memoriae are largely attested in the vast territories that were once part of the Roman Empire. These practices were aimed at transforming the narrative conveyed by monuments that originally honoured the now disgraced political leaders. ${ }^{6}$ Moreover, during Late Antiquity, a different sensibility towards monuments seems to have emerged in the area around the Mediterranean Sea. Traditionally, scholars have considered the spread of Christianity in this period as leading to the crystallisation of some wariness towards different religious beliefs, collectively redefined as unacceptably 'pagan.' ${ }^{7}$ According to this read-

tion and Heritage in Imperial Rome (Oxford: Oxford University Press, 2019). In this article the notion of 'heritage' in reference to the scrutinised late-antique phase is used to indicate buildings that were viewed, valued and engaged with in light of some awareness of their historical associations. For a similar approach, see Siwicki 2019 (op. cit. note 4), 13-17. Ann Marie Yasin is currently preparing a monograph concerning the strategies of architectural 'heritage' management, such as architectural destruction, renewal, and selective restaging of antiquities and architectural fragments, attested in the Graeco-Roman world. A.M. Yasin, Re-Building Histories: Architectural Temporality from Augustus to Justinian (book manuscript in preparation).

5 Susan Alcock defines monuments as such: "Rather than being versatile signposts of fastmoving social and cultural transformations, monuments stand unchanging, undisturbed by the kaleidoscope of human behaviour that surrounds them". S. Alcock, Archaeologies of the Greek Past: Landscape, Monuments, and Memories (Ann Arbor: Cambridge University Press, 2002), 28. See a similar definition in Osborne 2017 (op. cit. note 1), 181.

6 Recent research has largely reconsidered the notion of damnatio memoriae as a modern concept grouping together a wide range of diverse practices attested in the ancient Mediterranean area and intended to cancel, stain, recycle or eternalise monumental memories. See e.g. D. Kinney, "Spolia. Damnatio and Renovatio Memoriae." Memoirs of the American Academy in Rome (42) (1997) 117-148; E.R. Varner, Mutilation and Transformation:Damnatio Memoriae and Roman Imperial Portraiture (Leiden-Boston: Brill, 2004); H.I. Flower, The Art of Forgetting: Disgrace and Oblivion in Roman Political Culture (Chapel Hill: University of North Carolina Press, 2006); S. Benoist, ed., Un Discours en images de la condamnation de mémoire (Metz: Centre Régional Universitaire Lorrain d'Histoire, 2008).

7 Recent scholarship has argued that the use of the term 'pagan' to indicate ancient nonChristian cults and religious practices is fundamentally improper. During Late Antiquity, rather than strictly indicating religious commitment and/or indicating a single religiously defined community, 'pagan' and 'paganism' mainly referred to the lack of conformity to Christian (and/or Jewish) traditions. In this article, these terms are used to indicate multifaceted groups, symbols, rituals and cult practices that were not part of the Christian realm. The use of the terminology referring to 'Christianity' and 'Christians' requires a similar disclaimer. Just like 'paganism', in antiquity 'Christianity' did not entail either a single religious faith, nor a unified community or set of practices. The highly fragmented religious identities characterising Late Antiquity are not the focus of the present article and, for that reason, they are not 
ing, most visible outcome of the new late-antique religious receptiveness was the outburst of violent contestations against 'pagan' memorials, monuments and sculptural decorations. ${ }^{8}$ Late-antique literary sources effectively attest how statues, generally believed to be semi-animated objects, were gauged as particularly threatening in this historical phase. ${ }^{9}$ Similarly, archaeological remains of shattered temples, monuments, reliefs and inscriptions seem to confirm the occurrence of late-antique violent contestations against objects that publicly commemorated 'pagan' traditions. ${ }^{10}$ Moreover, imperial legislations of the time apparently show how official institutions were urged to address the discontent toward 'paganism' and its public exposure. ${ }^{11}$ Counter to the idea of a late-

discussed in further detail. For some interesting reflections on this topic, see e.g. G. Bonner, "The Extinction of Paganism and the Church Historian". The Journal of Ecclesiastical History (35) (3) (1984), 339-357; A. Cameron, Christianity and the Rhetoric of Empire. The Development of Christian Discourse (Berkeley: University of California Press, 1991), esp. 121-122; M. Salzman, "Rethinking Pagan-Christian Violence." In Violence in Late Antiquity: Perceptions and Practices, ed. H.A. Drake (Aldershot, UK: Ashgate, 2006), 265-285; I. Sandwell, Religious Identity in Late Antiquity: Greeks, Jews and Christians in Antioch (Cambridge, UK: Cambridge University Press, 2007); N. Belayche and S. Mimouni, eds., Entre lignes de partage et territoires de passage. Les identités religieuses dans les mondes grec et romain. "Paganismes", "judaïsmes", "christianismes", (Leuven: Peeters, 20o9); A. Cameron, The Last Pagans of Rome (Oxford: Oxford University Press, 2011), 14-32; C.P. Jones, "The Fuzziness of 'Paganism.'” Common Knowledge (18) (2) (2012), 249-254; A. Leone, The End of the Pagan City (Oxford: oxford University Press, 2013), 6-7; E. Rebillard, "Material Culture and Religious Identity in Late Antiquity." In A Companion to the Archaeology of Religion in the Ancient World, eds. R. Raja and J. Rüpke (Chichester: John Wiley, 2015), 425-436.

8 The debate about religious conflict during Late Antiquity is vast. For an updated overview on the major trends and scholarly approaches adopted to study this topic, see e.g. W. Mayer, "Religious Violence in Late Antiquity: Current Approaches, Trends and Issues." In Religious Violence in the Ancient World. From Classical Athens to Late Antiquity, ed. J.H.F. Dijkstra and C.R. Raschle (Cambridge: Cambridge University Press, 2020), 251-265. See e.g. L. James, “'Pray not to fall into temptation and be on your guard': antique statues in Byzantine Constantinople." Gesta (35) (1996), 12-20; B. Caseau, "Religious Intolerance and Pagan Statuary." In The Archaeology of Late Antique Paganism. Late Antique Archaeology 7, eds. L. Lavan and M. Mulryan (Leiden-Boston: Brill, 2011), 479-502.

10 See e.g. F.R. Trombley, "Paganism in the Greek World at the End of Antiquity: The Case of Rural Anatolia and Greece." The Harvard Theological Review (78) (3) (4) (1985), 327352; P. Stewart, "The destruction of statues in late antiquity", In Constructing Identities in Late Antiquity, ed. R. Miles (London: Routledge, 1999), 159-189; M. Mulryan, "'Paganism': Regional Studies and material culture." In The Archaeology of Late Antique Paganism. Late Antique Archaeology 7, eds. L. Lavan and M. Mulryan (Leiden—Boston: Brill, 2011), 83; T.M. Kristensen, "Driving the demons away: The word of Demeas." In Making and Breaking the Gods. Christian Responses to 'Pagan' Sculpture in Late Antiquity. Aarhus Studies in Mediterranen Antiquity 12, ed. T.M. Kristensen (Aarhus: Aarhus Universitetsforlag, 2013), 9-37.

The official imperial support for forms of 'de-paganisation' of urban sites is analysed in 
antique obliteration of 'pagan' monuments and a consequent Christianisation of monumental landscapes, recent scholarship has successfully demonstrated that non-Christian public spaces and memorials were not always targeted by acts of vandalism and/or destruction. Instead, the range of possible responses was much wider and included indifference but also aesthetical and historical appreciation. ${ }^{12}$ Hence, during Late Antiquity as today, the management of monuments fluctuated between cases of removal, preservation and recontextualisation.

Departing from the observation that alternative approaches coexist today as they did in Late Antiquity, this article adopts an historical perspective on the phenomenon of contesting monuments. Specifically, the focus is on the late-antique history of the so-called 'temple of Hadrian' at Ephesus, in ancient Asia Minor (see fig. 1; fig. 2, n. 40)..$^{13}$ The later treatment of this 'temple' provides informative material evidence about the administration of potentially troublesome non-Christian monuments during Late Antiquity. Dedicated to Artemis Ephesia, the emperor Hadrian and the city of Ephesus, and deco-

J. Hahn, "Public Rituals of Depaganisation in Late Antiquity." In Religious Practices and Christianisation of the Late Antique City (4th-7th cent.), ed. A. Busine (Leiden-Boston: Brill, 2015), 115-140.

12 See e.g. H. Saradi-Mendelovici, "Christian attitudes toward pagan monuments in Late Antiquity and their legacy in later Byzantine centuries." Dumbarton Oaks Papers (44) (1990), 47-61; J. Hahn, S. Emmel and U. Gotter, "From Temple to Church. Analysing a late antique phenomenon of transformation." In From Temple to Church. Destruction and Renewal of Local Cultic Topography in Late Antiquity, eds. J. Hahn, S. Emmel and U. Gotter (Leiden-Boston: Brill, 2008), 2-23; Caseau 2011 (op. cit. note 9); T.M. Kristensen and L. Stirling, "The Lives and Afterlives of Greek and Roman Sculpture: From Use to Refuse." In The Afterlife of Classical Sculpture: Late Antique Responses and Practices, eds. T.M. Kristensen and L. Stirling, (Ann Arbor: University of Michigan Press, 2016), 3-24; I. Jacobs, "Old statues, new meanings. Literary, epigraphic and archaeological evidence for Christian reidentification of statuary." Byzantinische Zeitschrift (113) (3) (2020), 789-836.

13 See e.g. H. Thür, "Das spätantike Ephesos. Aspekte zur Frage der Christianisierung des Stadtbildes." In Die spätantike Stadt und ihre Christianisierung. Symposion vom 14. Bis 16. Februar 2000 in Halle/Saale, eds. G. Brands and H.G. Severin (Wiesbaden: Reichert Verlag, 2003), 270-273; A.V. Pont, "Le Paysage Religieux Grec Traditionelle dans les Cités d'Asie Mineure Occidentale, au IV et au début du ve Siècle." Revue des Études Grecques (117) (2) (2004), 557-558; P. Talloen, S. Vercauteren, "The fate of temples in Late Antique Anatolia." In The Archaeology of Late Antique Paganism, Late Antique Archaeology 7, 1, eds. L. Lavan, M. Mulryan (Leiden-Boston: Brill, 2011), 361-363; I. Jacobs, "A tale of prosperity. Asia Minor in the Theodosian period." Byzantion (82) (2012), 130; U. Quatember, Der sogenannte Hadrianstempel an der Kuretenstraße. Forschungen in Ephesos 11, 3 (Wien:Verlag der Österreichischen Akademie der Wissenschaften 2018), 145; S. Ladstätter, "Ephesos from Late Antiquity until the Middle Ages. An Archaeological Introduction." In Ephesos from Late Antiquity until the Late Middle Ages, eds. S. Ladstätter and P. Magdalino (Wien: Verlag der Österreichischen Akademie der Wissenschaften, 2019), 22. 


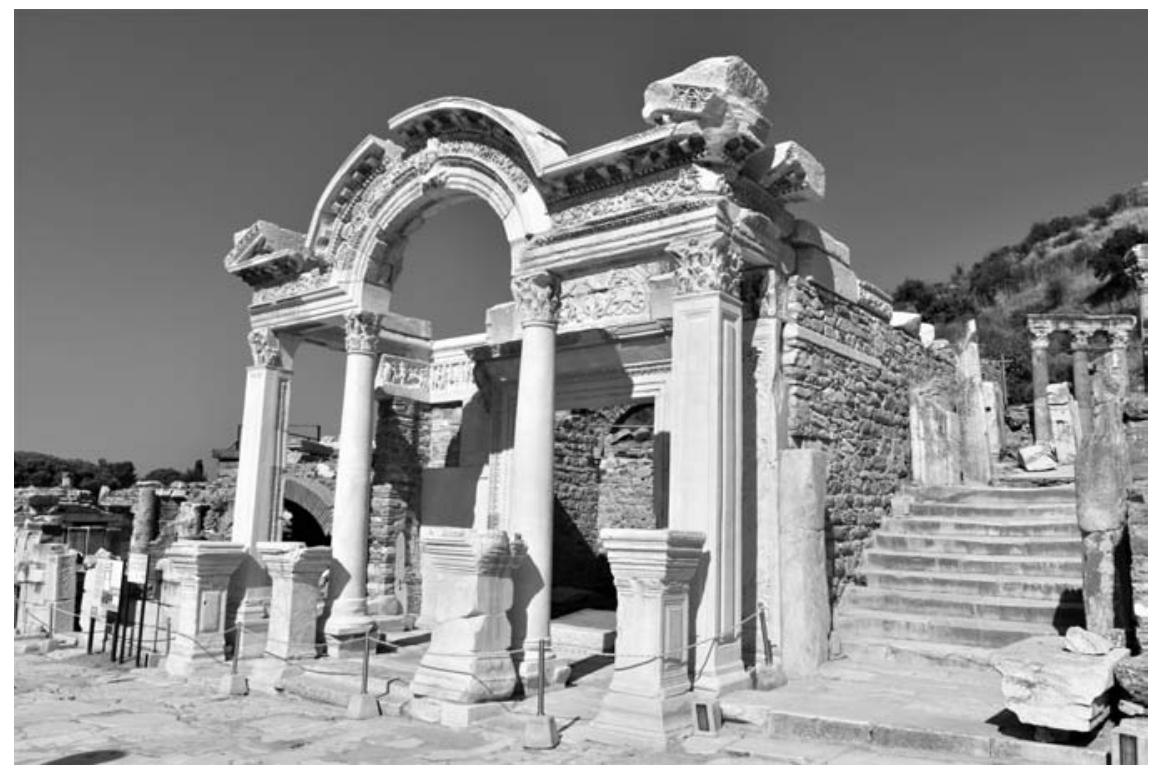

FIGURE 1 The so-called 'temple of Hadrian' at Ephesus PHOTO BY THE AUTHOR, OCTOBER 2019

rated by numerous sculpted images of heroes, gods and deified emperors, this building was unmistakably connected to the 'pagan' sphere in its first secondcentury CE configuration (see fig. $3-5) \cdot{ }^{14}$ Nevertheless, while during Late Antiquity many other Ephesian temples and 'pagan' monumental landmarks were left in ruins, destroyed and/or converted into churches, the 'temple of Hadrian' was kept in place until at least the sixth century CE. Even more, the 'temple' became the object of restorations and refurbishments.

14 Although traditionally identified as 'temple of Hadrian', there is no clear archaeological evidence for the interpretation of this building as a structure that hosted religious cults. In front of the temple, there is no space for the allocation of an altar and no cult statues have been found in connection with the building. On the other hand, the relation between this building and the sphere of the religious ceremonies performed along the Embolos is suggested by the topographical position, architectonical configuration, epigraphical apparatus and sculptural décor. These elements are discussed in further detail in the context of another article by the author focused on the reinterpretation of the second-century CE phase of the 'temple'. See K. Iannantuono, "Artemis, the divus Trajan and the demos in parade. A reinterpretation of the friezes at the so-called 'temple of Hadrian' at Ephesus." Jahreshefte des Österreichischen Archäologischen Institutes in Wien, forthcoming. 


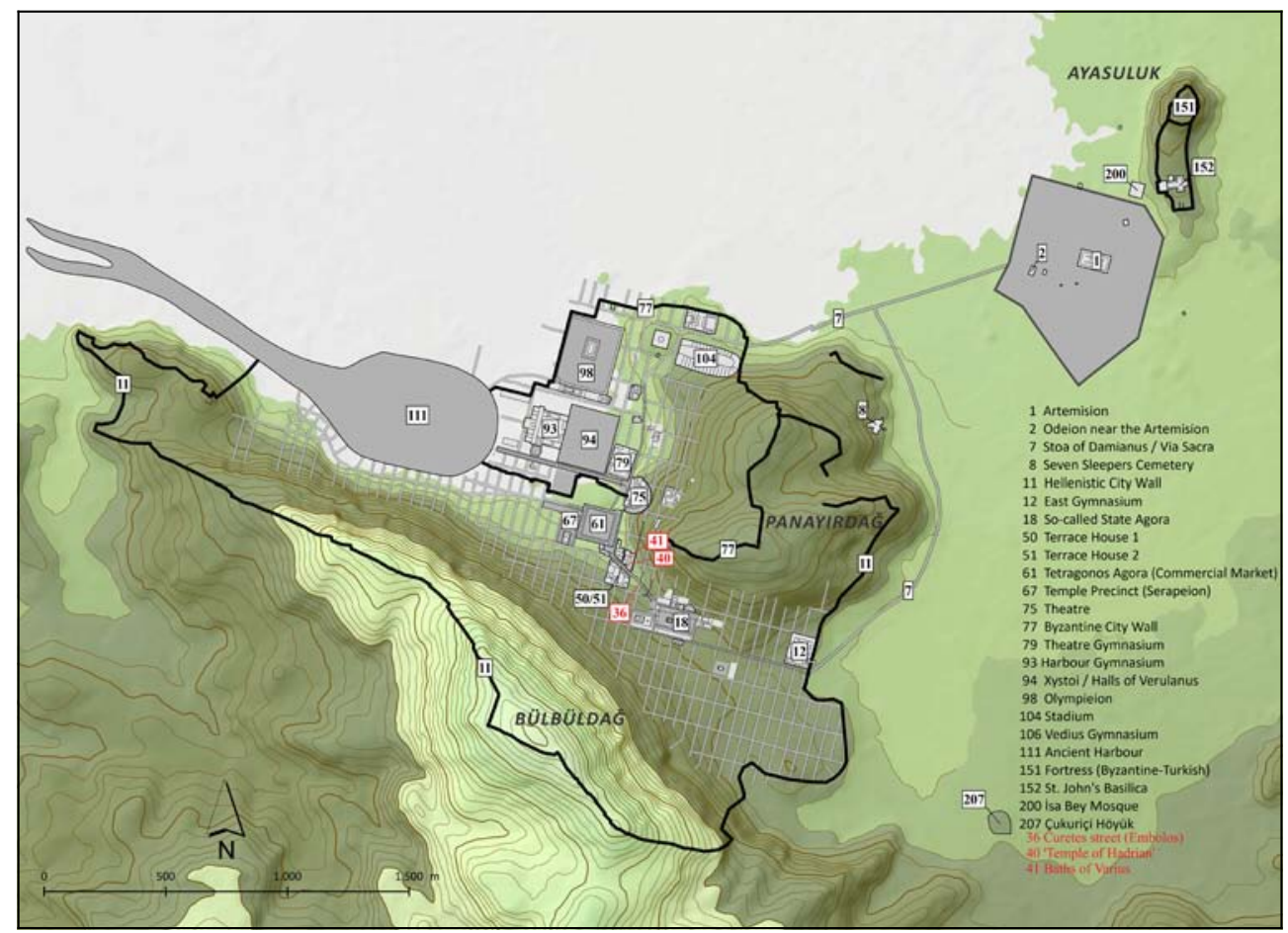

FIGURE 2 Map of the ancient city of Ephesus, with indication of the position of the 'temple of Hadrian' on the Embolos.

(c) ÖAI WITH MODIFICATION BY THE AUTHOR

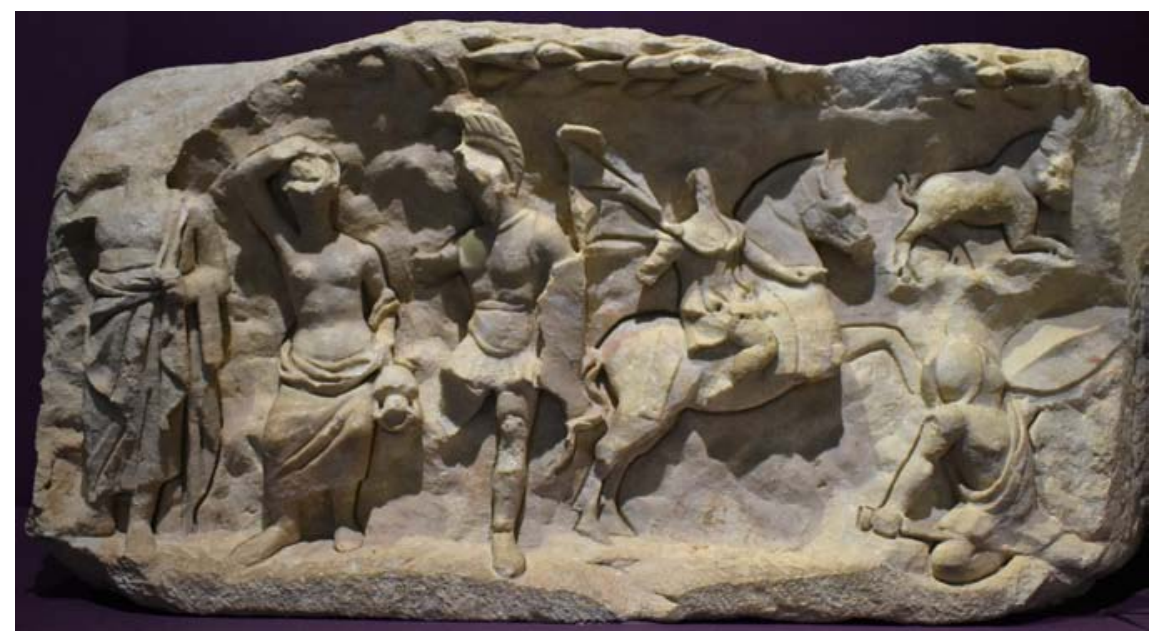

FIGURE 3 Relief at the Nord-West side of the pronaos of the 'temple of Hadrian' at Ephesus. In the depiction, scene from the myth of the city's foundation by the hero Androclus

PHOTO BY THE AUTHOR, OCTOBER 2019 


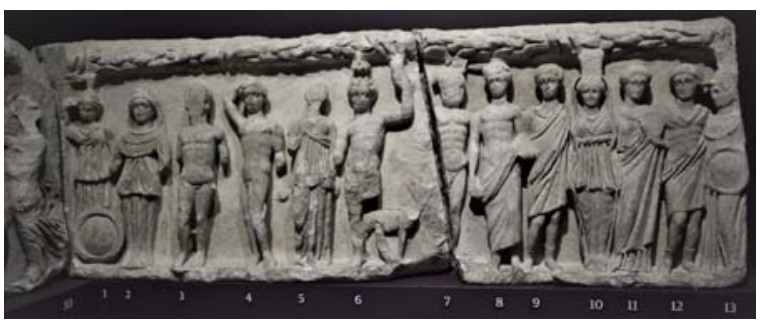

FIGURE 4 Relief originally decorating the South-East side of the pronaos of the 'temple of Hadrian' at Ephesus. At the centre of the depiction, a plausible representation of the emperor Trajan as divus, with the attributes of the goddess Artemis, and surrounded by a traditional gods, heroes and aristocrats of Ephesian importance PHOTO BY THE AUTHOR, OCTOBER 2019

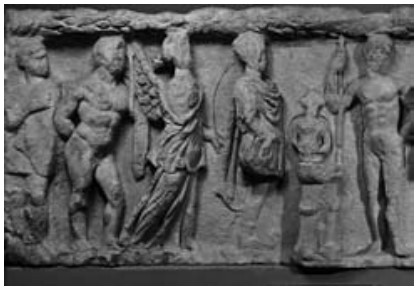

FIGURE 5

Detail of the relief originally decorating the Nord-East side of the pronaos of the 'temple of Hadrian' at Ephesus. In the depiction, plausible representation of the emperor (Hadrian?) in the act of sacrificing to the local gods while being crowned by a Nike

PHOTO BY THE AUTHOR, OCTOBER 2019

In this article, the practices of monumental removal, preservation and recontextualisation that occurred over time at the 'temple of Hadrian' at Ephesus are analysed in order to recognise possible motivations, agencies and outcomes. The aim is to acquire a better understanding of the management of this site in the changed religious, socio-political and urbanistic context of late-antique Ephesus. Moreover, by offering an historical perspective on these practices, this analysis offers a more neutral evaluation of the potential assets and flaws that characterise the alternative methods used for assessing contested monuments.

Before entering the analysis of the late-antique management of the 'temple of Hadrian' at Ephesus, I will offer a brief overview of the vast range of reactions to non-Christian monuments attested by late-antique literary sources and material evidence. Since the aim is to provide significant parallels for the inves- 
tigation of the late-antique transformations at the 'temple', specific attention is paid to the city of Ephesus and more in general to Asia Minor.

Just like many other major metropoles of the Roman Empire, Ephesus was a highly cosmopolitan and multicultural city. From the late second-early third century CE onwards, Ephesus became an important Christian centre, being the capital of the Asian diocese. At the same time, the city endured as a crucial urban node in the Mediterranean context, and as such it was inhabited by very diverse religious and social groups. ${ }^{15}$ Some tensions between these groups seem observable at the level of the late-antique transformations of the Ephesian cityscape. During Late Antiquity, many of the once outstanding Ephesian temples fell into ruins and/or were converted into churches. The Artemision, major pride of the city of Ephesus, was repeatedly plundered, and ultimately left to decay. ${ }^{16}$ After its notorious destruction perpetrated by groups of Goths in the year $263 \mathrm{CE}$, during the Tetrarchic age, the cella of the Artemision was restored with building materials taken from the ruins of the rest of the surrounding structure. ${ }^{17}$ Throughout the fourth century CE, the Artemision probably remained in use in this limited capacity. According to literary accounts, the patriarch John Chrysostom ordered the final despoiling of the temple in

15 S. Ladstätter and A. Pülz, "Ephesus in the Late Roman and Early Byzantine Period: Changes in its Urban Character from the Third to the Seventh Century AD." In The Transition to Late Antiquity. On the Danube and Beyond. Proceedings of the British Academy 141, ed. A.G. Poulter (Oxford-New York: Oxford University Press, 2007), 408-416.

16 On the late-antique fate of the Artemision, see C. Foss, Ephesus after Antiquity. A Late Antique, Byzantine and Turkish City (Cambridge: Cambridge University Press, 1979), 3o, 86-87; P. Chuvin, Chronique des derniers païens. La disparition du paganisme dans l'Empire romain, du règne de Constantin à celui de Justinien (Paris: Fayard, 199o), 55-56; F.R. Trombley, Hellenic religion and Christianisation c. 370-529. 1 vol. (Leiden-Boston: Brill, 1994), 96; R. Cormack, "The temple as cathedral", In Aphrodisias Papers 1, eds. C. Roueché and K.T. Erim (Portsmouth: Journal of Roman Archaeology Supplements, 199o), 75-88; P. Scherrer, Ephesos. Der neue Führer. 100 Jahre österreichische Ausgrabungen 1895-1995 (Wien: Verlag der Österreichischen Akademie der Wissenschaften, 1995), 21; A. Bammer and U. Muss, "Die Kirche im Artemision von Ephesos." In Efeso paleocristiana e Bizantina-Frühchristliches und Byzantinisches Ephesos, eds. O. Kresten, F. Krinzinger, R. Pillinger and E. Russo (Wien: Verlag der Österreichischen Akademie der Wissenschaften, 1999), 86-88; Thür 2003 (op. cit. note 13), 266-267; Pont 2004 (op. cit. note 13), 557-558; Talloen, Vercauteren 2011 (op. cit. note 13), 348, 369; Jacobs 2012 (op. cit. note 13), 126; U. Muss, "The Artemision in Early Christian Times." Early Christianity (3) (7) (2016), 293-312. For the difficulties in the reconstruction of this fate on the basis of the data from the early excavations conducted by John Turtle Wood in 1869, see B. Ward-Perkins, "The End of the Temples: An Archaeological Problem." In Spätantiker Staat und religiöser Konflikt. Imperiale und lokale Verwaltung und die Gewalt gegen Heiligtümer, ed. J. Hahn (Berlin: De Gruyter, 2011), 190.

See e.g. Foss 1979 (op. cit. note 16), 86. 
the early-fifth century CE, on the occasion of his visit to Ephesus. ${ }^{18}$ Whether or not these accounts are to be considered reliable, archaeological evidence attest that during Late Antiquity, the debris of the Artemision were looted as a major source of materials and spolia which were then reused in the construction of new buildings at Ephesus, such as the baths of Constantius and the churches of Saint Mary and Saint John. ${ }^{19}$ Finally, in the sixth century CE, a small church was built inside the temple's sekós (its internal open court area). ${ }^{20}$ In the meanwhile, the shrines at the Upper or State Agora, such as the peripteral temple at the centre of the square and the small temenos at the West of the prytaneion, were abandoned. ${ }^{21}$ The temple of the Sebastoi (divine Augusti) that once overlooked the Upper Agora and the lower side of the city shared a similar fate. ${ }^{22}$ The so-called Serapeion, one of the most impressive examples of the Ephesian religious architecture, was converted into a church. ${ }^{23}$ More drastically, the socalled Olympieion, a massive temple in honour of the emperor Hadrian in the harbour district, was razed to its foundations. Eventually, a church was con-

18 Palladius, Dialogus de vita Joannis Chrysostomi, ed. P.R. Coleman-Norton (Cambridge: Cambridge University Press, 1928), 13; Cyril of Alexandria, Homilia 11 (Patrologia Graeca vol. 77), 1031-1032; Proclus of Constantinople, Oratio 20, 3 (Patrologia Graeca vol. 65), 832. Cf. Theodoret, Historia ecclesiastica 5, 29. Cf. R.C. Kukula, "Literarische Zeugnisse über den Artemistempel von Ephesos und inschriftliche Zeugnisse über das Artemision." In Forschungen in Ephesos 1 (Wien: Verlag der Österreichischen Akademie der Wissenschaften, 1906), 237-282.

19 U. Muss, A. Bammer and M. Büyükkolancı, Der Altar des Artemisions von Ephesos (Wien: Verlag der Österreichischen Akademie der Wissenschaften, 2001), 28-29.

$20 \quad$ See e.g. Muss 2016 (op. cit. note 16), 310-312.

21 For the different interpretations of these temples, see D. Steuernagel, "The Upper Agora at Ephesos: an Imperial Forum?" In Religion in Ephesos Reconsidered. Archaeology of Spaces, Structures, and Objects, eds. D. Schowalter, S. Ladstätter, S.J. Friesen and C. Thomas (Leiden-Boston: Brill, 2019), 93-107. For their state in Late Antiquity, see Thür 2003 (op. cit. note 13), 262; Jacobs 2012 (op. cit. note 13), 126.

22 J. Keil, Ephesos. Ein Führer durch die Ruinenstätte und ihre Geschichte 5 (Wien: Verlag der Österreichischen Akademie der Wissenschaften, 1964), 124; Pont 2004 (op. cit. note 13), 557; Talloen, Vercauteren 2011 (op. cit. note 13), 356; Jacobs 2012 (op. cit. note 13), 126.

23 W. Alzinger, "Ephesos B. Archäologische Teil." RE Supplement (12) (1970), 1652-1654; Foss 1979 (op. cit. note 16), 64; R.A. Bayliss, Provincial Cilicia and the Archaeology of Temple Conversion (Oxford: Archaeopress, 2004), 25; P. Scherrer, ed., Ephesus: The New Guide (Istanbul: Ege Yayinin, 2000), 148-150; Pont 2004 (op. cit. note 13), 557-558; Jacobs 2012 (op. cit. note 13), 128. For the results of the recent investigations at the site of the Austrian Archaeological Institute, see T. Schultz, "The So-called Serapeion in Ephesos: First Results of the Building Research." In Religion in Ephesos Reconsidered. Archaeology of Spaces, Structures, and Objects, eds. D. Schowalter, S. Ladstätter, S.J. Friesen and C. Thomas (Leiden—Boston: Brill, 2019), 41-61. 
structed on this temple's foundations. ${ }^{24}$ All together this evidence seems to attest to a progressive diminishing of the Ephesian 'pagan' monumental landscape. In contrast, the city appears to have been increasingly Christianised during Late Antiquity. ${ }^{25}$

Similar trends seem to be attested by contemporary literary sources. ${ }^{26} \mathrm{In}$ late-antique texts, contesting 'pagan' temples, monuments and especially statuary as evidence of idolatry is often described as the inevitable outcome of increasing tensions in a changing society. ${ }^{27}$ From as early as the fourth century $\mathrm{CE}$ and increasingly in the fifth and sixth century $\mathrm{CE}$, hagiographies indulged in narratives of monks, holy men, saints and bishops leading Christian communities in the damaging, tearing down and removal of 'pagan' sculptures from public spaces. ${ }^{28}$ The interpretation of hagiographies needs to be conducted with extreme carefulness, however. Saints' lives were primarily meant as rhetor-

24 In the years immediately preceding the Council of Ephesus (431 CE), a small church dedicated to Mary was erected on the site of the so-called Olympieion. This church was monumentalised in the late fifth century CE. See, S. Karwiese, Die Marienkirche in Ephesos: Erster vorläufiger Grabungsbericht 1984-1986, (Wien: Verlag der Österreichischen Akademie der Wissenschaften, 1989), 18-20; Thür 2003 (op. cit. note 13), 265, 267; Pont 2004 (op. cit. note 13), 557-558; Talloen, Vercauteren 2011 (op. cit. note 13), 356, 364; Jacobs 2012 (op. cit. note 13$), 126$.

25 On the Christianisation of the city, see e.g. Thür 2003 (op. cit. note 13), 259-273.

26 For an overview on the Christian responses to Roman art as described in second-century CE literary sources, see L.S. Nasrallah, Christian Responses to Roman Art and Architecture: The Second-Century Church Amid the Spaces of Empire (Cambridge: Cambridge University Press, 2010).

27 See e.g. Tertullian, De Spect. 8; Eunapius, Vitae sophistarum 7, 2, 9-10; Ambrose, Ep. 18; Augustine, Ep. 16.1; Ep. 102, 3; De consensu evangelistarum 1, 16; Libanius, Or. 30.8-9.

28 Already in the fourth century CE, such narratives are present in the Life of Constantine by Eusebius, in which the emperor is reported to have ordered the removal of a shrine dedicated to Aphrodite from the site of the Holy Sepulchre. Eusebius, Vita Constantinii 3, 26-27. Similar examples are reported in e.g. Vita Marcelli 6-7; Vita Porphyrii 57-53. On the recurrence of this theme in hagiographies see also C. Mango, "Antique statuary and the byzantine beholder." Dumbarton Oaks Papers (17) (1963), 55-56. For an overview on these sources, see James 1996 (op. cit. note 28), 12-20; B. Caseau, "Rire des dieux: Les rituels de dérision contre les statues païennes à Byzance." In La dérision au Moyen Âge: de la pratique sociale au rituel politique, eds. E. Crouzet-Pavan and J. Verger (Paris: Presses Universitaires de Paris-Sorbonne, 2007), 117-141. Interestingly, these literary accounts are often connected to bishops, as narrators, like in the case of Eusebius, bishop of Caesarea, or as protagonists of the action, like in the case of Martin, Porphyry, Marcellus, Theophilus. For the role of bishops in this phenomenon, see e.g. G. Fowden, "Bishops and Temples in the Eastern Roman Empire AD 320-435." Journal of Tourism and Heritage Studies (29) (1978), 53-78; M. Whitby, "Factions, Bishops, Violence and Urban Decline." In Die Stadt in der Spätantike-Niedergang oder Wandel?, eds. J.-U. Krause and C. Witschel (Stuttgart: Franz Steiner Verlag, 2006), 441-461. 
ical devices for preaching. Their focus was the celebration of saints through the narration of their extraordinary actions: exaggeration was thus a noticeable characteristic of the genre. ${ }^{29}$ Moreover, not all hagiographies present uniform accounts. In some cases, the visit to a 'pagan' site is not motivated by a desire for its annihilation. An alternative topos recurrent in hagiographic texts is that of saints moving into abandoned temples in order to find remote places to retreat from the world, without any destructive aim. ${ }^{30}$

Late-antique imperial legislation is another often used source of information about the contestation of 'pagan' monuments. Anti-pagan laws started to be promulgated under Constantine, but only during the Theodosian age were there imperial pronouncements that focused specifically on the administration of temples and statuary. ${ }^{31}$ In the year $399 \mathrm{CE}$, a decree issued by the emperor Theodosius I ( $\mathrm{r}$. 379-395 CE) underscored the need to differentiate between statues and idols, and to destroy those last ones. ${ }^{32}$ Later, in $408 \mathrm{CE}$, a more rigorous decree was issued to command the destruction of simulacra and altars set in temples and shrines. ${ }^{33}$ Further imperial laws ordered the removal of sacred statues from public spaces where these could have attracted forms of veneration. ${ }^{34}$ In this same period, several episodes of violence against temples and statuary are attested, particularly in the Eastern provinces of the Empire. For instance, the destruction of the Serapeum of Alexandria, in Egypt, directed by the bishop Theophilus in the year $392 \mathrm{CE}$, resonates in many contemporary literary sources. ${ }^{35}$ Similarly, literary accounts narrate the devastations perpetrated by Christian groups at the temple of Marnas at Gaza, in Palestine, and at that of Zeus at Apamea, in Syria. ${ }^{36}$ As discussed, literary sources also con-

29 See e.g. H.G. Saradi, "The Christianisation of pagan temples in the Greek hagiographical texts." In From Temple to Church. Destruction and Renewal of Local Cultic Topography in Late Antiquity, eds. J. Hahn, S. Emmel, U. Gotter (Leiden—Boston: Brill, 2008), 113-134.

See e.g. Vita S. Gregorius Thaumaturgus (Patrologia Graeca vol. 46), 916-917; Vita Ilarioni, 133, 24-29; Vita Epiphanii (Patrologia Graeca vol. 53), 89-92. Cf. Saradi 2008 (op. cit. note 29), $115^{-116 .}$

31 For the Constantinian anti-pagan legislation, see T.D. Barnes, "Constantine's Prohibition of Pagan Sacrifice." American Journal of Philology (105) (1984), 69-72.

32 Codex Theodosianus 16, 10, 18.

33 Codex Theodosianus 16, 10, 19.

34 Codex Theodosianus 16, 10, 20.

35 J. Hahn, "The conversion of the cult statues: the destruction of the Serapeum 392 A.D. and the transformation of Alexandria into the 'Christ-loving' city." In From Temple to Church. Destruction and Renewal of Local Cultic Topography in Late Antiquity, eds. J. Hahn, S. Emmel and U. Gotter (Leiden-Boston: Brill, 2008), 337-339, with references.

36 A. Busine, "From Stones to Myth: Temple Destruction and Civic Identity in the Late Antique Roman East." Journal of Late Antiquity (6) (2) (2014), 325-346. 
nect the final wreckage of the Ephesian Artemision to the violence of Christian mobs guided by the bishop John Chrysostom. ${ }^{37}$

Despite the relative abundance of references to the wariness reserved to the management of monuments, a close reading of the Theodosian anti-pagan legislation shows that indiscriminate acts of destruction were never permitted. Instead, imperial laws demanded only the neutralization of those monuments that were still objects of veneration. In many cases, the violent actions perpetrated against 'pagan' temples and monuments by holy men and zealous monks were openly condemned by secular authorities and even by bishops. ${ }^{38}$ In the oration Pro Templis, the rhetor Libanius demonstrates that temples and shrines were effectively defended by the laws. ${ }^{39}$ As a matter of fact, imperial legislation insisted on the need to keep temples open and to preserve statues in case these were appreciable for their artistic value. ${ }^{40}$ In other words, aesthetic and historical significance were recognised as criteria for the discrimination of objects as part of a 'cultural heritage' worthy of preservation and protection. ${ }^{41}$

The relevance of similar notions in Late Antiquity can be argued also by looking at the material record from the time. Sculptures representing 'pagan' mythological heroes and traditional gods continued to be appreciated, maintained on display, relocated, re-used as spolia, and even newly commissioned well into Late Antiquity. ${ }^{42}$ For instance, the emperor Constantine decorated fourth-century CE Constantinople with sculptures taken from other cities all over the Empire, mostly depicting themes connected to traditional religion and mythology. ${ }^{43}$ In order to be credible as new capital of the Empire, the city was in need of a proper sculptural apparatus that could demonstrate prestige at an

37 Cf. supra note 18.

38 M. Salzam, "Rethinking Pagan-Christian Violence." In Violence in Late Antiquity: Perceptions and Practices, ed. H.A. Drake (Aldershot, UK: Ashgate, 2006), 272-273.

39 Libanius, Orationes 19, 8.

40 Codex Theodosianus 16, 10, 18.

41 See e.g. A.V. Pont, Orner la cité. Enjeux culturels et politiques du paysage urbain dans l'Asie gréco-romaine (Bordeaux: Ausonius, 2009); A. Bravi, "Ornamenta, Monumenta, Exempla. Greek Imagaes of Gods in the Public Spaces of Constantinople." In Divine Images and Human Imaginations in Ancient Greece and Rome, ed. J. Mylonopoulos (Leiden-Boston: Brill, 2010), 289-301; I. Jacobs, Aesthetic Maintenance of Civic Space. The "Classical" City from the 4 th to the 7 th $c . A D$., Orientalia Lovaniensia Analecta 193 (Leuven-Paris-Walpole, MA: Peeters, 2013).

42 For Asia Minor, see e.g. I. Jacobs, "Production to Destruction? Pagan and Mythological Statuary in Late Antiquity." American Journal of Archaeology (114) (2010), 267-303.

43 Eusebius, Vita Constantinii 3, 54, 2-4; Eunapius, V. Soph. 6, 1, 5; Libanius, Orationes 30, 6 and 37; Zosimus 2, 31-32; John Malalas 13,7. 
economical, historic, artistic and representative level. ${ }^{44}$ Images of traditional gods and heroes continued to populate the public spaces of Constantinople long after. In fifth-century CE Constantinople, a vast collection of statues representing deities and mythological figures of the Greek tradition adorned the Lauseion, an outstanding palace described by the chronicler Joannes Zonara as: "the splendour of the city". ${ }^{45}$ The palace and the statuary collection were owned by the eunuch Lausus who served as praepositus sacricubiculi (chamberlain) at the court of Theodosius II (r. 4O2-45 O CE) and who was a devoted Christian. ${ }^{46}$ Possibly, the statues collected by Lausus were regarded as spoils plundered from 'pagan' sanctuaries, and they were appropriated in order to signify the triumph of Christianity. ${ }^{47}$ On the other hand, the relocation of these antiquities in the new context of Lausus' palace, suggests a genuine artistic appreciation of these objects. ${ }^{48}$ Publicly displayed at the Lauseion, the sculptural ensemble staged traditional images within a reconstructed historical continuity that aimed at glorifying the maiestas of Byzantine Constantinople and, by proxy, the status of Lausus as member of the Constantinopolitan elite. ${ }^{49}$

During Late Antiquity, similar public displays of sculptural decorations depicting traditional religious-mythological figures remained common also in other parts of the Empire. At Antioch, an early fifth-century CE collection displayed in a private villa included depictions of figures such as Meleager, Dionysus, Ares, Apollo, a Satyr, and Aphrodite-some of these statues were even newly realised in the fourth century CE. ${ }^{50}$ At Carthage, a statuette depicting Ganymede and Zeus as an eagle was displayed at the fifth-century CE 'House of

44 Mango 1963 (op. cit. note 28), 55-75; S.G. Bassett, "The Antiquities in the Hippodrome of Constantinople." Dumbarton Oaks Papers (45) (1991), 87-96; Jacobs 2010 (op. cit. note 42), 290.

45 On the palace, see J. Bardill, "The Palace of Lausus and nearby monuments in Constantinople: a topographical study." American Journal of Archaeology (101) (1) (1997), 69-75. On the collection of statues, see C. Mango, M. Vickers, and E.D. Francis, "The Palace of Lausus at Constantinople and Its Collection of Ancient Statues", Journal of the History of Collections (4) (1992), 89-98; S. Guberti Bassett, "Excellent offerings: the Lausos collection in Constantinople", The Art Bulletin (82) (2000), 6-25.

46 See PLRE 2, Lausus 1, 66o-661.

47 Mango, Vickers and Francis 1992 (op. cit. note 45), 93; Bardill 1997 (op. cit. note 45), 69; Guberti Bassett 2000 (op. cit. note 45), 16.

48 Guberti Bassett 2000 (op. cit. note 45), 19.

49 A. Bravi 2010 (op. cit. note 41), 294-295. See also A. Bravi, Griechische Kunstwerke im politischen Leben Roms und Konstantinopels (Berlin: De Gruyter, 2014).

50 D.M. Brinkerhoff, A collection of Sculpture in classical and early Christian Antioch (New York: New York University Press, 1971), 7-28. 
the Mosaic of the Greek Charioteers.' ${ }^{51}$ In Gaul, the late-antique villa at SaintGeorges-de-Montagne, nearby modern Bordeaux, was decorated by fourthcentury CE sculptures of Artemis, Aphrodite with a Triton, and Cupids. ${ }^{52}$ All these examples demonstrate that images previously perceived as being tied to the religious-mythological sphere were still in use during Late Antiquity. ${ }^{53}$ Rather than triggering violent reactions, often statues of gods and heroes were collected as status symbols. In general, during Late Antiquity, traditional monumental art seems to have lost its connections with non-Christian traditions and rituals. Once detached from cultual practices, items depicting traditional religious-mythological images exited the realm of religious objects and were demoted to the sphere of cultural artefacts worthy of being preserved and valorised. ${ }^{54}$

Similar relocations and reuses of statues depicting traditional gods are also attested in late-antique Ephesus. The sculptural décor originally adorning the Ephesian East Gymnasium and depicting 'pagan' deities and heroes, for example, was most probably grouped together and transferred inside the Kaisersaal and the propylon of the complex. This relocation is of particular significance, since in the fifth century CE, the East Gymnasium hosted a church in the rooms of the former baths. ${ }^{55}$ Another example of relocation is that of the panel reliefs depicting the military victories of Lucius Verus against the Parthians originally decorating the Ephesian altar of Caesar which were de-assembled, moved and reused in a disordered way as spolia for the transformation of the library of Cel-

$5^{1} \quad$ E.K. Gazda, "A Marble Group of Ganymede and the Eagle from the Age of Augustine." In: Excavations at Carthage 6, ed. J.H. Humprey (Ann Arbor: University of Michigan Press, 1977), 125-178.

52 E. Espérandieu, Recueil général des bas-reliefs de la Gaule romaine, 2 Aquitaine (Paris: Impr. nationale, 1908), 221-224, nos. 1243-125o.

53 A similar example is that of the so-called 'Esquiline group', a cycle of Aphrodisian sculptures depicting mythological subjects plausibly produced in the fourth century CE or associated with new inscriptions at that date. See B. Kiilerich and H. Torp, "Mythological sculpture in the fourth century A.D.: the Esquiline group and the Silahtarağa statues", Istanbuler Mitteilungen 44 (1994), 307-316.

54 A. Corso, "Attitudes to the Visual Arts of Classical Greece in Late Antiquity." Eulimene (2001), 13-51.

55 M. Aurenhammer, Die Skulpturen von Ephesos. Bildwerke aus Stein. Idealplastik I, Forschungen in Ephesos 10, 1 (Wien: Verlag der Österreichischen Akademie der Wissenschaften, 199o), 44, 6o, 95; F. Yegül, Baths and Bathing in Classical Antiquity (New York-Cambridge -London: MIT Press, 1992), 279-282; J. Auinger and E. Rathmayr, "Zur spätantiken Ausstattung der Thermen und Nymphäen in Ephesos." In Statuen in der Spätantike, eds. F.A. Bauer and C. Witschel (Wiesbaden: Reichert Verlag Wiesbaden, 2007), 242; Jacobs 2010 (op. cit. note 42), 293, n. 6. 
sus into a nymphaeum. ${ }^{56}$ In late-antique Ephesus, statuary representing 'pagan' figures was even newly commissioned. Between the end of the fourth and the beginning of the fifth century $\mathrm{CE}$, a sculptural ensemble depicting subjects such as Christian crosses, a kantharos, but also theatrical masks, Dionysus, Eros, a satyr, and Harpokrates was produced and displayed at the fountain nearby the stadium. ${ }^{57}$ In mid-fifth-century CE Ephesus, a monumental arch, the so-called 'gate of Herakles' was built at the Eastern end of the Embolos, not distant from the 'temple of Hadrian'. This arch was decorated by reused sculptural panels depicting Herakles and the Nemean Lion, as well as reliefs of flying Nikes. ${ }^{58}$

Statues and monuments devoted to the commemoration of emperors constituted a liminal category. At times, these objects presented images of emperors as divinised and/or as dedicatees of cults. ${ }^{59}$ Nonetheless, throughout Late Antiquity, the damaging of imperial statues continued to be subject to heavy sanctions. ${ }^{60}$ Imperial statues were still largely perceived as important loci of the representation of the emperor's powers. The attention still paid to imperial statuary is observable through the treatment that this category of materials attracted during Late Antiquity, and especially at times of socio-political turmoil. The speeches of Libanius and the homilies by John Chrysostom attest that a riot burst out in Antioch in $387 \mathrm{CE}$ in response to a considerable increase in taxation, decreed by an imperial edict. ${ }^{61}$ During the riot, the Antiochians ripped down wooden panels displaying the emperor's portrait and damaged bronze statues of the imperial family. The reaction to these actions by the emperor Theodosius I was not lenient: he threatened to strip the city of several

$56 \quad$ Foss 1979 (op. cit. note 16), 3; Auinger, Rathmayr 2007 (op. cit. note 55), 250; Jacobs 2010 (op. cit. note 42), 294, n. 14; Kristensen 2013 (op. cit. note 10), 9, $13,15$.

57 Jacobs 2010 (op. cit. note 42), 271, with references.

58 A. Bammer, "Das Denkmal des C. Sextilius Pollio in Ephesos." Jahreshefte des Österreichischen Archäologischen Institutes in Wien (51) (1976-1977), 78-92; C. Roueché, "The Image of Victory: New Evidence from Ephesus." In Mélanges Gilbert Dagron, ed. V. Déroche (Paris: Association des Amis du Centre d'Histoire et Civilisation de Byzance, 2002), 537; A. Pülz, Das sog. Lukasgrab in Ephesos. Eine Fallstudie zur Adaption antiker Monumente in byzantinischer Zeit, Forschungen in Ephesos 4, 4 (Wien: Verlag der Österreichischen Akademie der Wissenschaften 2010), 550; Ladstätter 2019 (op. cit. note 13), 22.

59 L. Lavan, "Political Talismans? Residual 'Pagan' Statues In Late Antique Public Space." In The Archaeology of Late Antique Paganism. Late Antique Archaeology 7, eds. L. Lavan and M. Mulryan (Leiden-Boston: Brill, 2011), 459.

6o J. Pollini, "Gods and Emperors in the East: Images of Power and the Power of Intolerance." In The Sculptural Environment of the Roman Near East. Reflections on Culture, Ideology and Power, ed. Y.Z. Eliav, E.A. Friedland and S. Herbert (Leuven: Peeters, 2008), 168.

61 John Chrysostom, Homiliae ad populum Antiochenum de statuis (Patrologia Graeca vol. 49), 21; Libanius, Orationes 19-23. 
privileges, cut off the annona, and close down the city's hippodrome, theatres and baths. Furthermore, many members of the city council responsible for the destructions were imprisoned. ${ }^{62}$ Theodosius' punitive response to the destruction of his statues and monuments proves the relevance that imperial images continued to hold in the lateantique world. ${ }^{63}$ Yet, at times, statues and reliefs that represented emperors were still targeted by acts of violence. ${ }^{64}$ At Ephesus, the colossal portraits of the Flavian emperors once displayed in the cella of the temple of the Sebastoi were broken into pieces and reused as building material for later structures. ${ }^{65}$ Establishing the responsibility and the timing of these actions proves particularly complex. The outcomes of Domitian's damnatio memoriae or instead some forms of Christian reprisal are both potentially viable motives that cannot be singled out from other possible causes. ${ }^{6} 6$

In some other instances, archaeological evidence can be more surely understood as resulting from Christian reactions. ${ }^{67}$ The carving of Christian symbols on 'pagan' monuments is a good example. ${ }^{68} \mathrm{~A}$ female portrait exhibited at

62 For the riot and the evaluations of John Chrysostom's and Libanius' accounts, see R. Browning, "The Riot of AD 387 in Antioch." Journal of Roman Studies (42) (1952), 15-16; H. Leppin, "Steuern, Aufstand und Rhetoren: Der Antiochener Steueraufstand von 387 in christlicher und heidnischer Deutung." In Gedeutete Realität. Krisen, Wirklichkeiten, Interpretationen (3.-6. Jh. n. Chr.), ed. H. Brandt (Stuttgart: Franz Steiner Press, 1999), 103-123; S. Mitchell, A History of the Later Roman Empire AD284-641: The transformation of the ancient world (Oxford: Blackwell, 2007), 325; Sandwell 2007 (op. cit. note 7), 129, 173-174; M. Kahlos, "The Emperor's New Images: How to Honour the Emperor in the Christian Empire." In Emperors and the Divine: Rome and its Influence, ed. M. Kahlos (Helsinki: Helsinki Collegium for Advanced Studies, 2016), 127-130.

63 The same Codex Theodosianus, after all, prescribed that local officials should have be present whenever a statue was dedicated to the emperor. See, Codex Theodosianus 15, 4, 1.

64 See e.g. Pollini 2008 (op. cit. note 6o), 171, for some interesting considerations about the systematic defacement of the busts of emperors and deities decorating the crowns of the statues representing agonothetai in Asia Minor.

65 Foss 1979 (op. cit. note 16), 30; Bayliss 2004 (op. cit. note 23), 38. At the site, also a fresco of Demeter displayed in a room adjacent to the temple was obscured by whitewash.

66 See, K. Iannantuono, "Forgetting Domitian at Ephesus: Practices of imperial commemoration and disgrace at the temple of the Sebastoi at Ephesus in Asia Minor", in preparation.

67 See e.g. F.R. Trombley, "The Destruction of Pagan Statuary and Christianisation (FourthSixth Century c.E.)." In The Sculptural Environment of the Roman Near East. Reflections on Culture, Ideology, and Power, eds. Y.Z. Eliav, E.A. Friedland and S. Herbert, (Leuven: Peeters, 2008), 143-164; Jacobs 2010 (op. cit. note 42); Caseau 2011 (op. cit. note 9); M.T. Kristensen, "Miraculous bodies: Christian viewers and the transformation of 'pagan' sculpture in Late Antiquity." In Patrons and viewers in Late Antiquity, Aarhus Studies in Mediterranean Antiquity 10, eds. S. Birk and B. Poulsen (Aarhus: 2012), 31-66; Jacobs 2020 (op. cit. note 12), 791-799.

68 On the phenomenon of cross-carving of statues, or sphragis, see e.g. Saradi-Mendelovici 
the Ephesian fountain so-called 'Straßenbrunnen' was marked by a cross, and left on display as such..$^{69}$ In the area of this fountain, archaeological investigations also unearthed a torso of Dionysus with the genitals removed and a relief depicting a phallus and marked by a small cross. ${ }^{70}$ Crosses were also carved on the foreheads of many Ephesian statues representing deities, or semi-divine figures like emperors. Two colossal imperial portraits of Augustus and Livia which once stood in the chalcidicum of the basilica in the Upper Agora, for example, were famously marked by the carving of crosses on their forehead (see fig. 6). ${ }^{71}$ The two statues, together with another 'de-paganised' portrait of Augustus, were then demolished and their fragments were re-used as building material for the pavement of a sixth-century CE peristylium grown on top of the basilica at the Lower Agora. ${ }^{72}$ As is the case with the statues at the temple of the Sebas$t o i$, this last act of destruction need not necessarily to be interpreted as a form of violence perpetrated by Christians, however. ${ }^{73}$ In the early sixth century CE, the building of the basilica was destroyed, and it is therefore not impossible that the statues were broken into pieces on that occasion. ${ }^{74}$ Further sculpted representations of crosses appeared on many buildings at Ephesus, particularly on the Embolos. At the beginning of the street, a large public fountain was decorated with slabs of marble decorated with large sculpted crosses. ${ }^{75}$ Further down the street, a cross monument substituted a former statue of Artemis. As recorded by the dedicatory inscription carved on the surviving base of this cross

1990 (op. cit. note 12), 54; N. Hannestad, "How did rising Christianity cope with Pagan Sculpture?" In East and West: Modes of Communication. Proceedings of the First Plenary Conference at Merida, eds. E. Chrysos and I. Wood (Leiden—Boston: Brill, 1999), 183-184; B. Caseau, "La désacralisation des espaces et des objects religieux païens durant l'antiquité tardive." In Le sacré et son inscription dans l'espace à Byzance et en occident, ed. M. Kaplan (Paris: Éditions de la Sorbonne, 2001), 120; Bayliss 2004 (op. cit. note 23), 59-6o; Trombley 2008 (op. cit. note 67), 157; Jacobs 2010 (op. cit. note 42), 279-28o; Kristensen 2012 (op. cit. note 67$), 5^{2-53}$.

69 Auinger, Rathmayr 2007 (op. cit. note 55), 254; Jacobs 2010 (op. cit. note 42), 295, n. 19.

70 For the statue of Dionysus, see Aurenhammer 1990 (op. cit. note 55), 63-64, n. 42, pls. 29cd; Auinger, Rathmayr 2007 (op. cit. note 55), 254; Jacobs 2010 (op. cit. note 42), 295, n. 19 . For the relief, see Kristensen 2012 (op. cit. note 67), 47, 58, n. 4, fig. 9, with references. On the 'Straßenbrunnen', see U. Quatember, “Der Brunnen an der Straße zum Magnesischen Tor in Ephesos." Jahreshefte des Österreichischen Archäologischen Institutes in Wien (77) (2008), 219-264.

71 Jacobs 2010 (op. cit. note 42), 280, with references.

72 Alzinger 1970 (op. cit. note 21), 262; Kristensen 2012 (op. cit. note 67), 45-47. A third statue head of Augustus was found in the same context. Jacobs 2010 (op. cit. note 42), 280 .

73 Jacobs 2010 (op. cit. note 42 ), 28 o.

74 Foss 1979 (op. cit. note 16), 82.

75 Foss 1979 (op. cit. note 16), 69. 


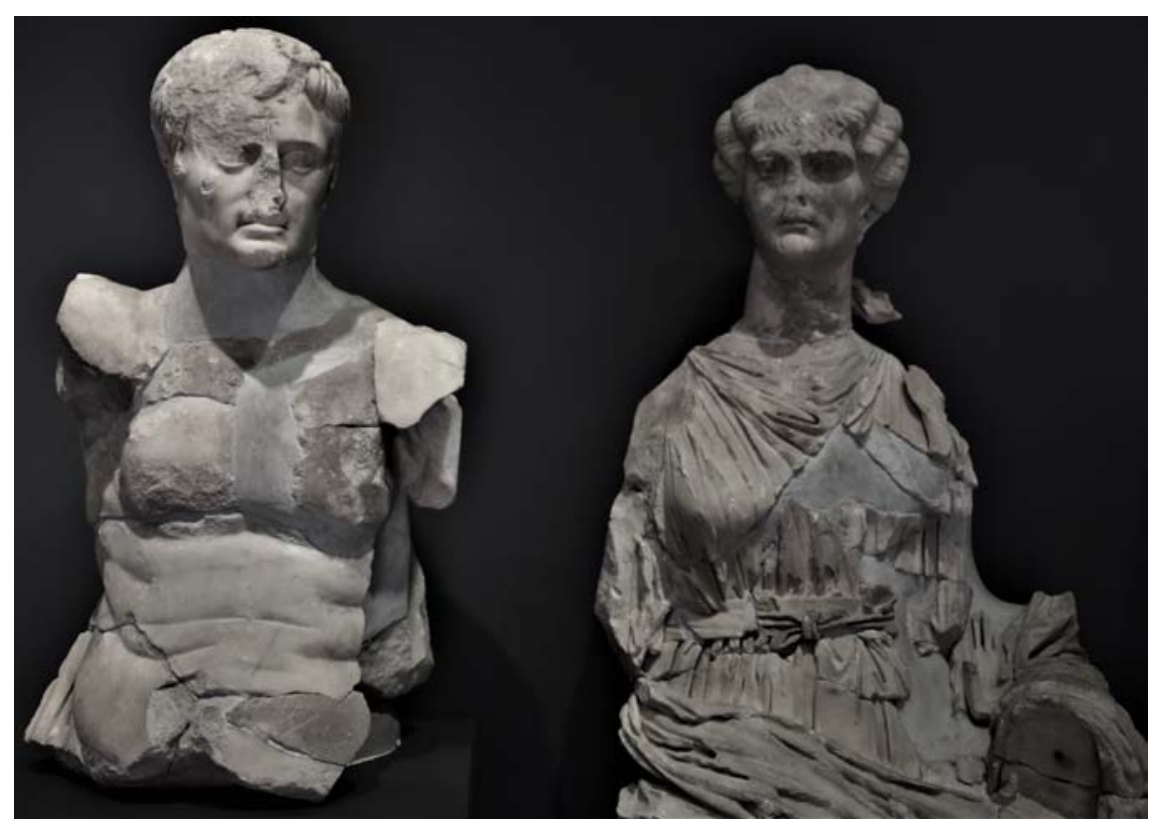

FIGURE 6 'Christianised' portraits of Augustus and Livia from Ephesus PHOTO BY THE AUTHOR, OCTOBER 2019

monument, the Christian Demeas was to be praised for this new display. ${ }^{76}$ The erection of the cross and the inscription were directed not only at the glorification of Christianity but also at the commemoration of the event of the removal itself. In modern cultural studies, equal operations are described as examples of counter-monumentality. ${ }^{77}$ Acting as counter-monuments, the inscription and

76 O. Benndorf, Forschungen in Ephesos 7 (Wien: Verlag der Österreichischen Akademie der Wissenschaften, 1906), 103; H. Thür, Das Hadrianstor in Ephesos. Forschungen in Ephesos 11, 1 (Wien: Verlag der Österreichischen Akademie der Wissenschaften, 1989), 129-131; Jacobs 2010 (op. cit. note 42), 286; Kristensen 2013 (op. cit. note 10), 9-21.

77 The practice of realizing Gegendenkmal (counter-monuments) arose in Germany in the 198 os and 199os, in reaction to the need to acknowledge the Holocaust and other Second World War atrocities in some commemorative form. See e.g. A. Forty, "Introduction." In The Art of Forgetting, eds. A. Forty and S. Küchler (Oxford-New York: Oxford University Press, 1999), 6-7; A. Huyssen, "Monumental seduction." New German Critique (69) (1996), 181-20o. The most recent notion of counter-monumentality has been extended to include not only works of art erected to counter balance a contested monument but also dynamic practices operated on the original object subject to controversy. See, J.E. Young, "The counter-monument: Memory against itself in Germany Today." Critical Inquiry (18) (1992), 267-296; Forty 1999 (op. cit. note 77), 10-12; R. Crownshaw, "The German countermonument: conceptual indeterminacies and the retheorisation of the arts of vicarious 


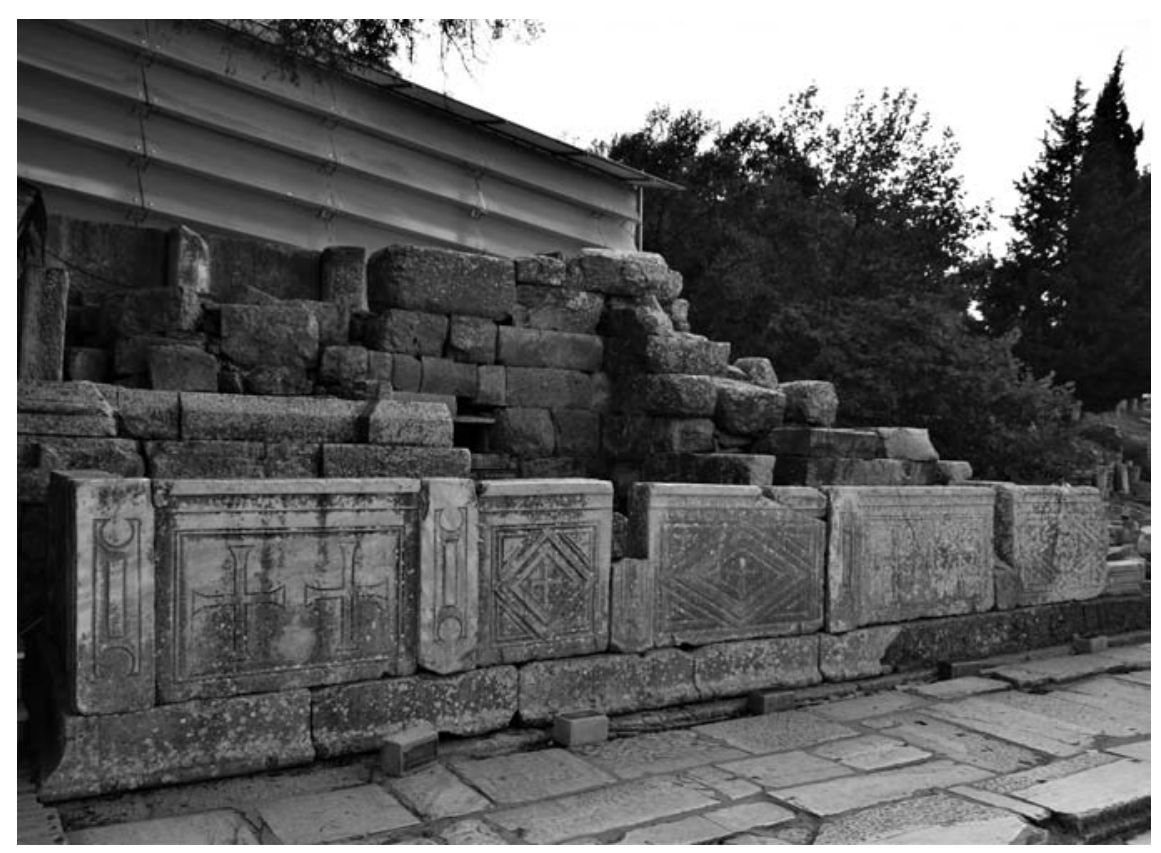

FIGURE 7 Heroon of Androclus on the Embolos at Ephesus PHOTO BY THE AUTHOR, OCTOBER 2019

the cross were aimed at subverting the previous 'pagan' narrative. As a result the site was appropriated and turned into a Christian lieu de mémoire. ${ }^{78}$ Along the Embolos, other monuments were marked by Christian symbols. For instance, the heroon of the mythical founder of the city, Androclus, was transformed into a fountain by the addition of three marble slabs decorated by large sculpted crosses (see fig. 7) ${ }^{79}$ Some of the blocks of the structures of the 'Baths of Varius' were also carved with crosses. ${ }^{80}$

memory." Forum for Modern Language Studies (44) (2) (2008), 212-227; G. Moshenska, "Charred churches or iron harvests? Counter-monumentality and the commemoration of the London Blitz." Journal of Social Archaeology (10) (2010), 21-23; Q. Stevens, K.A. Franck, R. Fazakerley, "Countermonuments: the anti-monumental and the dialogic." Journal of Architecture (17) (6) (2012), 951-972; C.M. Watts, "Counter-monuments and the Perdurance of Place." Cambridge Archaeological Journal 28 (3), 379-393.

78 For the notion of "lieu de mémoire", see P. Nora, "Between Memory and History: Les Lieux de Mémoire", Representations (26) (1989), 7-24.

79 H. Thür, "Der ephesische Ktistes Androklos und (s)ein Heroon am Embolos." Jahreshefte des Österreichischen Archäologischen Institutes in Wien (64) (1995), 80-97; Kristensen 2012 (op. cit. note 67), 49 .

8o $\quad$ Foss 1979 (op. cit. note 16), 70. 
Christian intervention on 'pagan' monuments can be detected also by looking at subtractions. The management of the sculptural décor of the Ephesian nymphaeum of C. Laecanius Bassus, for example, attests a highly selective Christian intervention: the statues of river gods, tritons and satyrs displayed there were deprived of their genitals and tails, the parts potentially perceived as most 'offensive' by the Christian audience. ${ }^{81}$ Other statues displayed at the nymphaeum Traiani, ${ }^{82}$ at the fountain of Pollio, ${ }^{83}$ at the fountain nearby the stadium, ${ }^{84}$ at the 'Straßenbrunnen, ${ }^{85}$ at the gymnasium of Vedius, ${ }^{86}$ and at the library of Celsus, ${ }^{87}$ were treated in the same manner. Even an imperial likeness of a naked Lucius Verus as Mars that was exhibited at the Ephesian bouleuterion triggered the same reaction and had its genitals cut off. ${ }^{88}$

Famously, the same phenomenon of erasure is attested at the Julio-Claudian Sebasteion at Aphrodisias. ${ }^{89}$ On the two-hundred surviving reliefs, all visibly exposed genitalia appear to have been removed in antiquity. ${ }^{90}$ Moreover, nine of the surviving eighty reliefs along the South building were systematically and visibly defaced. On the vandalised reliefs, figures were carefully hacked off in such a way that their absence would have been immediately visible. In contrast, images of emperors, deities and mythological figures populating the rest of the iconographies displayed on these reliefs were left undamaged. The only targeted images seem to have been those particularly tied with the dimension of non-Christian rituals, and potentially appealing for a 'pagan' audience. ${ }^{91}$ Given the specific nature of the alterations, these can probably be connected to a

81 Aurenhammer 199 o (op. cit. note 55), 84, 85, 88-92, 124, 153-156; Auinger, Rathmayr 2007 (op. cit. note 55 ), 252-253.

82 Aurenhammer 1990 (op. cit. note 55), 31, 41, 51, 104; Auinger, Rathmayr 2007 (op. cit. note 55), 250-251; Jacobs 2010 (op. cit. note 42), 294, n. 15.

83 Aurenhammer 1990 (op. cit. note 55), n. 147; Auinger, Rathmayr 2007 (op. cit. note 55), 252; Jacobs 2010 (op. cit. note 42), 295, n. 16.

84 Auinger, Rathmayr 2007 (op. cit. note 55), 249; Jacobs 2010 (op. cit. note 42), 294, n. 13.

85 Auinger, Rathmayr 2007 (op. cit. note 55), 254; Jacobs 2010 (op. cit. note 42), 295, n. 19.

86 Auinger, Rathmayr 2007 (op. cit. note 55), 245-248; Jacobs 2010 (op. cit. note 42), 293, n. 5 .

87 Auinger, Rathmayr 2007 (op. cit. note 55), 250; Jacobs 2010 (op. cit. note 42), 94, n. 14.

88 London, British Museum 1256, GR 1865.12-6.1. See, Auinger, Rathmayr 2007 (op. cit. note 55), 257; M. Aurenhammer, T. Opper (eds.), The Bouleuterion at Ephesos. Forschungen in Ephesos 9, 5 (Wien: Verlag der Österreichischen Akademie der Wissenschaften, 2011), 111.

89 R.R.R. Smith, "Defacing the Gods at Aphrodisias." In Historical and Religious Memory in the Ancient World, eds. B. Dignas, R.R.R. Smith (eds.), (Oxford—New York: Oxford University Press, 2012), 283-326.

$90 \quad$ Smith 2012 (op. cit. note 89 ), 308.

91 Images of standing or enthroned deities, scenes of sacrifices and of crowning of gods, for example were subject to actions of scratching, defacement and erasure. See Smith 2012 (op. cit. note 89), 97-98. 
Christian response. ${ }^{92}$ The erasures of the most problematic elements were conducted very carefully, avoiding in this way any unnecessary damage to the rest of the monuments. ${ }^{93}$ Clearly, the main goal was the overall preservation of the targeted objects, but deprived of their more disturbing aspects, and therefore desensitised.

In all Asia Minor there is only scarce archaeological evidence of the continued use of sites connected to the 'pagan' sphere during Late Antiquity. ${ }^{94}$ However, this shortage of evidence does not prove an abrupt interruption of ancient rituals nor a far-reaching violent destruction of more traditional religious landscapes. ${ }^{95}$ For instance, at Aphrodisias, the temple of Aphrodite stayed in use as a place of pagan worship until the fifth century $\mathrm{CE}$, when it was converted into a Christian church. ${ }^{96}$ Public dedications to the goddess Aphrodite are also attested in the city as late as the fifth century CE. ${ }^{97}$ Similarly, the Sebasteion remained in use until the fifth century CE. ${ }^{98}$ Moreover, in fifthcentury CE Aphrodisias, the atrium of a private house was converted to more public use, plausibly turning into a Neoplatonic school, and it was decorated by a series of sculpted portrait shields of classic philosophers, such as Pindar, Socrates and Pythagoras, as well as contemporary thinkers and acolytes. ${ }^{99}$ At this site, the public display of statuary referring to non-Christian traditions endured until at least the mid sixth century CE, when the shield portraits were removed, damaged, and discarded. ${ }^{100}$ In the same city, until the sixth century

92 See e.g. Smith 2012 (op. cit. note 89), 306.

93 Smith 2012 (op. cit. note 89), 307-308.

94 Talloen, Vercauteren 2011 (op. cit. note 13), 348-349.

95 For the performance of pagan rituals in private contexts during Late Antiquity, see R. MacMullen, Christianity and Paganism in the Fourth to Eighth Centuries (New Haven-London: Yale University Press, 1997), 61-63, 106-107. For late-antique pagan rituals at rural sites, see also B. Caseau, "The Fate of Rural Temples in Late Antiquity and the Christianisation of the Countryside." In Recent Research on the Late Antique Countryside. Late Antique Archaeology 2, eds. W. Bowden, L. Lavan and C. Machado (Leiden-Boston: Brill, 2004), 114-117, 134-136.

96 R.R.R. Smith, "Late Antique Portraits in a Public Context: Honorific Statuary at Aphrodisias in Caria, A.D.300-6oo." The Journal of Roman Studies (89) (1999), 157-158.

97 C. Roueché, Aphrodisias in Late Antiquity. The Late Roman and Byzantine Inscriptions Including Texts from the Excavations at Aphrodisias Conducted by Kenan T. Erim. Journal of Roman Studies Monographs, 5 (London: Society for the Promotion of Roman Studies, 1989), 153-154.

98 R.R.R. Smith, "The Imperial Reliefs from the Sebasteion at Aphrodisias." The Journal of Roman Studies (77) (1987), go.

99 R.R.R. Smith, "Late Roman Philosopher Portraits from Aphrodisias." The Journal of Roman Studies (80) (1990), 130.

100 Smith 1990 (op. cit. note 99), 155 . 
$\mathrm{CE}$, the sculptural décor at the Hadrianic baths was continuously updated via the inclusion of re-used high-imperial sculptures depicting traditional deities and mythological subjects. ${ }^{101}$ Finally, at the theatre at Aphrodisias, a statue of Apollo was left on public display until the seventh century CE. ${ }^{102}$ Similarly, at Sagalassos, 'pagan' statuettes were publicly exhibited until the seventh century CE. ${ }^{103}$ At Ephesus, statuettes representing various deities, like Athena, Apollo, Poseidon, Dionysus, Aphrodite, Nemesis and Herakles, stood at the theatre during Late Antiquity. ${ }^{104}$ Statues depicting 'pagan' characters were left undisturbed at other Ephesian sites: the so-called Fontäne, ${ }^{105}$ the Harbor Baths, ${ }^{106}$ and, also, the same 'Baths of Varius. ${ }^{107}$ Significantly, all these sites continued to be in use during Late Antiquity. ${ }^{108}$ The overlooking of these statues, therefore, may have been the result of more than a seemingly neutral attitude. Instead, conscious appreciation and even active processes of preservation and valorisation could have motivated the conservation of these sculptures, which at that point were not recognised as problematic.

To sum up, the consideration of both literary and material evidence suggests the coexistence in Late Antiquity of multiple responses to the numerous elements of civic decorum that held some connections to the 'pagan' sphere. As it has been observed in the case of modern responses to contested monuments, the variegated late-antique practices can be grouped in the categories of remov-

101 R.R.R. Smith, "Statuary life in the Hadrianic Baths at Aphrodisias, AD 10o-6oo: local context and historical meaning," In Statuen in der Spätantike, eds. F.A. Bauer and C. Witschel (Wiesbaden: Reichert Verlag Wiesbaden, 2007), 208-209, 215-216.

102 K.T. Erim and R.R.R. Smith, "Sculpture from the Theatre: a preliminary report," In Aphrodisias Papers 2. JRA Supplements 2, eds. R.R.R. Smith and K.T. Erim (Portsmouth: Journal of Roman Archaeology Supplements, 1991) 68-98.

103 I. Jacobs and L. Stirling, "Re-using the gods: a 6th-c. statuary display at Sagalassos and a re-evaluation of pagan mythological statuary in Early Byzantine civic space." Journal of Roman Archaeology (30) (2017), 197-226.

104 Aurenhammer 199 o (op. cit. note 55), nos. 5, 12, 15, 32, 34, 53, 79, 98; Jacobs 2010 (op. cit. note 42), 296, 30 .

105 Auinger, Rathmayr 2007 (op. cit. note 55), 253; Jacobs 2010 (op. cit. note 42), 295, n. 18.

106 Auinger, Rathmayr 2007 (op. cit. note 55), 238-240; Jacobs 2010 (op. cit. note 42), 293, n. 4.

107 Aurenhammer 1990 (op. cit. note 55), nos. 38, 49, 83, 94.

108 The late-antique use of the so-called Fontäne is epigraphically attested by the later statue bases for the emperors Constantius II and Constans erected there. See Auinger, Rathmayr 2007 (op. cit. note 55), 253; Jacobs 2010 (op. cit. note 42), 295, n. 17. In the same period, the Harbor Baths were restored by the proconsul Caelius Montius. See Foss 1979 (op. cit. note 16), 79. For the late-antique use of the Ephesian theatre, see Foss 1979 (op. cit. note 16), 56. For the late-antique restorations of the 'Baths of Varius' by the Christian Scholastica, cf. infra note 149 . 
ing, preserving, and recontextualising. ${ }^{109}$ The dramatic image of a late-antique end of 'pagan' cities traced by the literary sources needs to be counterweighted by the testimony of these different approaches. ${ }^{110}$ Moreover, even when the loss of 'pagan' monumental 'heritage' is effectively attested by the archaeological record, often the connection of these events with Christian agencies cannot be ascertained. The mercilessness of time and the violence of earthquakes, especially in a highly seismic region like Asia Minor, need to be taken into account as possible causes behind the destruction of many archaeological sites and artefacts connected to non-Christian tradition. ${ }^{111}$ In addition, multiple other factors, chiefly economical, can be held accountable for the destruction of 'pagan' monuments and sites during Late Antiquity. In absence of the financial backing from imperial or aristocratic evergetism, temples were progressively left in decay, and eventually abandoned. ${ }^{112}$ The missed restoration of many damaged temples is surely indicative of the loss of relevance of these spaces as public archives of collective memories. On the other hand, the hypothesis of a Christian ideological appropriation of the cities of Asia Minor is not corroborated by the archaeological evidence. ${ }^{113}$ Even more, there is evidence of symbolic acts having taken place during the closure of damaged temples that seem to attest that certain ancient 'pagan' landmarks preserved meaning, at least for some groups. The handling of three statues of Artemis at the prytaneion at Ephesus is a good example of this phenomenon. After the collapse of the prytaneion, the three statues, still perfectly conserved, were intentionally buried in situ. This burial reflects an attempt to ritually close the site, and possibly to spare the statues from later damage. ${ }^{114}$

109 For a useful overview on the late-antique fate of mythological and 'pagan' sculpture in Asia Minor, see Jacobs 2010 (op. cit. note 42), 293-298.

110 For similar considerations about the specific situation of late-antique North Africa, see Leone 2013 (op. cit. note 7 ), 8o-82.

111 For the difficulties in recognizing the causes and dating these phenomena, see e.g. T.M. Kristensen, "Earthquakes and Late Antique Urbanism: Some Observations on the Case of the Lykos Valley [Depremler ve Gec Antik Kentlesme: Lykos Vadisi Örnegi Üzerine Bazi Gözlemler]." In The Lykos Valley and Neighbourhood in Late Antiquity [Gec Antik Cag'da Lykos Vadisi ve Cevresi], eds. C. Şimşek and T. Kacar (Istanbul: Ege Yayinlari, 2018), 71-78, with further references.

112 C. Sotinel, "L' abandon des lieux de culte païen." In Proceedings of the Atelier thématique Hellénisme et Christianisme, Villejuif, Octobre 2001, ed. E. Rebillard, M. Narcy (Lille-Paris, Presses Universitaires du Septentrion, 2004), 35-6o.

113 Lavan 2011 (op. cit. note 59), 470.

114 Scherrer 2000 (op. cit. note 23), 86. The statues were found lying face upwards inside a stratigraphical layer just above the pavement of the building. The deposition, therefore, has been interpreted as intentional. See Jacobs 2010 (op. cit. note 42), 297, n. 37, with references. 


\section{A Small 'Temple' on the Embolos: First Configuration and Late-Antique Interventions}

Turning back to the case study at the centre of this article, the so-called 'temple of Hadrian' at Ephesus was unearthed in 1956 by a research team of the Austrian Archaeological Institute ( $\ddot{O A I})$ under the direction of the archaeologist Franz Miltner (see fig. 1). ${ }^{115}$ Between the years 2009 and 2014, a research team of the $\ddot{O A I}$ directed by Sabine Ladstätter and coordinated by Ursula Quatember conducted new research into the site. The new studies have helped to clarify the different phases of construction and restoration of the 'temple', and its function. ${ }^{116}$

The 'temple', a small tetrastyle prostyle in antis in Corinthian order, stands right at the heart of ancient Ephesus, overlooking a major axis of the city, the Curetes street or Embolos (see fig. 2, nn. 36 and 40). Following an ancient processional route connecting the Upper and Lower Agoras with the Artemision (via Sacra), the Embolos was a main site of commemoration and selfrepresentation. ${ }^{117}$ Placed in such a prominent position, the 'temple' was part of a larger building complex developed over the entire insula and including baths and a public latrine. ${ }^{118}$ Overlooking the Embolos, the 'temple' - together

115 F. Miltner, "xx. Vorläufiger Bericht über die Ausgrabungen in Ephesos." Jahreshefte des Österreichischen Archäologischen Institutes in Wien (42) (1955), 23-6o. Two years later, in 1958, the anastylosis of the temple, carried out under the supervision of Miltner and the architect Karl Heinz Göschl, was completed. See, F. Miltner, "XXI. Vorläufiger Bericht über die Ausgrabungen in Ephesos." Jahreshefte des Österreichischen Archäologischen Institutes in Wien (43) (1956-1958), 6-8.

116 For the outcomes of this new research on the 'temple', see Quatember 2018 (op. cit. note 13). For a discussion of the previous literature, see Iannantuono forthcoming (op. cit. note 14).

117 An Ephesian inscription refers to the Embolos as "the magnificent ground of the city". See, $I V E 4$, 1300. On the importance of this street, see e.g. H. Thür, "Zur Kuretenstrasse von Ephesos: eine Bestandsaufnahme der Ergebnisse aus der Bauforschung." In Neue Forschungen zur Kuretenstrasse von Ephesos, ed. S. Ladstätter, (Wien: Verlag der Österreichischen Akademie der Wissenschaften, 2009), 9-28. A. Waldner, Die Chronologie der Kuretenstrasse. Archäologische Evidenzen zur Baugeschichte des unteren Embolos von Ephesos von der lysimachischen Neugründung bis in die byzantinische Zeit (Wien: Verlag der Österreichischen Akademie der Wissenschaften, 2020).

118 The contemporaneity between the temple and the baths has been doubted by e.g. F. Hüber, Ephesos. Gebaute Geschichte (Mainz am Rhein: Philipp von Zabern, 1997), 86-88. The contemporaneity of the planning and erection of the baths and the 'temple of Hadrian' on the Embolos, however, has been finally proved by the recent archaeological and architectonical research of the ÖAI. Architectonically, the temple was connected with the 'Baths of Varius' at its Western side, through stairs giving direct access to the thermal complex in 
with the stairs' doorway located at its South-Eastern side-constituted a monumentalised entrance hall for the so-called 'Baths of Varius'.119

Aiming at the monumentalisation of the baths, the 'temple' is very richly decorated. Its façade is characterised by a Syrian arch surmounted by a Tyche's protome wearing a mural crown. ${ }^{20}$ The entablature of the 'temple' is decorated by plant motifs, featuring palmettes, acanthus spirals, erotes, panthers and 'Rankenfrauen' (busts of naked women emerging from acanthus leaves). ${ }^{121}$ The façade is also enriched by the presence of a dedicatory inscription engraved on the three bands of the architrave just above the Syriac arch. ${ }^{122}$ Addressing Artemis, the emperor and the city, this dedication displayed a formula recurrently seen on Ephesian buildings of the second century CE. ${ }^{123}$ The dedi-

the back. The doorway of the stairs was surmounted by a prolongation of the architrave of the temple's façade. See Quatember 2010 (op. cit. note 117), 385-387; Quatember 2018 (op. cit. note 13), 54-55, pl. 99, 203. The new studies have also clarified some architectonical peculiarities previously misinterpreted. Specifically, the longitudinal overstretching of the building, the small dimension of the cella and the predominance of the pronaos and the façade in the overall articulation of the temple, have been connected to the structure's specific function. See, Quatember 2018 (op. cit. note 13), 54.

119 As attested by epigraphic evidence, the whole complex was funded by the same commissioners, the Ephesians P. Quintilius Valens Varius, his wife and his daughter Quintilia Varilla. See, $I v E$ 2, 429; $I v E 455 ; I v E$ 500, 59o. See also Miltner 1956-1958 (op. cit. note 115), 17-27; F. Miltner, "XxII. Vorläufiger Bericht über die Ausgrabungen in Ephesos." Jahreshefte des Österreichischen Archäologischen Institutes in Wien (44) (1959), 251-256; H. Vetters, "Ephesos: Vorläufiger Grabungsbericht 1969." Anzeiger: Österreichische Akademie der Wissenschaften, Wien (107) (1970), 120-121; Yegül 1992 (op. cit. note 55), 288-291.

120 Miltner 1959 (op. cit. note 119), 265, fig. 126. For the architectonic decorations of the temple see also Quatember 2018 (op. cit. note 13), 93-95, with references.

121 For the architectonical and sculptural decoration of the façade, see Quatember 2018 (op. cit. note 13), 89-104.

122 Miltner 1959 (op. cit. note 119), 265-266; $A E ́$ 1962, 184; $A E ́$ 1967, 469; E.L. Bowie, "The Temple of Hadrian at Ephesus." Zeitschrift für Papyrologie und Epigraphik (8) (1971), 137-141; E.L. Bowie, "The Vedii Antonini and the temple of Hadrian at Ephesus." In The Proceedings of the Xth International Congress of Classical Archaeology, Ankara-Izmir 1973, ed. E. Akurgal (Ankara: Türk Tarih Kurumu, 1978), 867-874; H. Engelmann, "Der Tempel des Hadrian in Ephesos und der Proconsul Servaeus Innocens." Zeitschrift für Papyrologie und Epigraphik (9) (1972), 91-96; M. Wörrle, "Zur Datierung des Hadrianstempels an der Kuretenstraße in Ephesos." AA (1973), 470-477; SEG 29, 1111; IVE 2, 429.

123 For the dedicatory inscription, see Miltner 1959 (op. cit. note 119), 265-266; $A E ́$ 1962, 184; AÉ 1967, 469; Bowie 1971, 137-141; 1978, 867-874; Engelmann 1972, 91-96; Wörrle 1973, 470-477; $S E G 29$, 1111; $I v E 2,429$. For the use of the same formula for the dedication of other buildings at Ephesus, see B. Burrell, "False Fronts: Separating the Aedicular Facade from the Imperial Cult in Roman Asia Minor." AJA (110) (2006), 442; A.S. Graham, "The Word is Not Enough: A New Approach to Assessing Monumental Inscriptions. A Case Study from Roman Ephesos." AJA (117) (3) (2013), 337-338; D. Van der Linde, "Artemis Ephesia, the Emperor and 


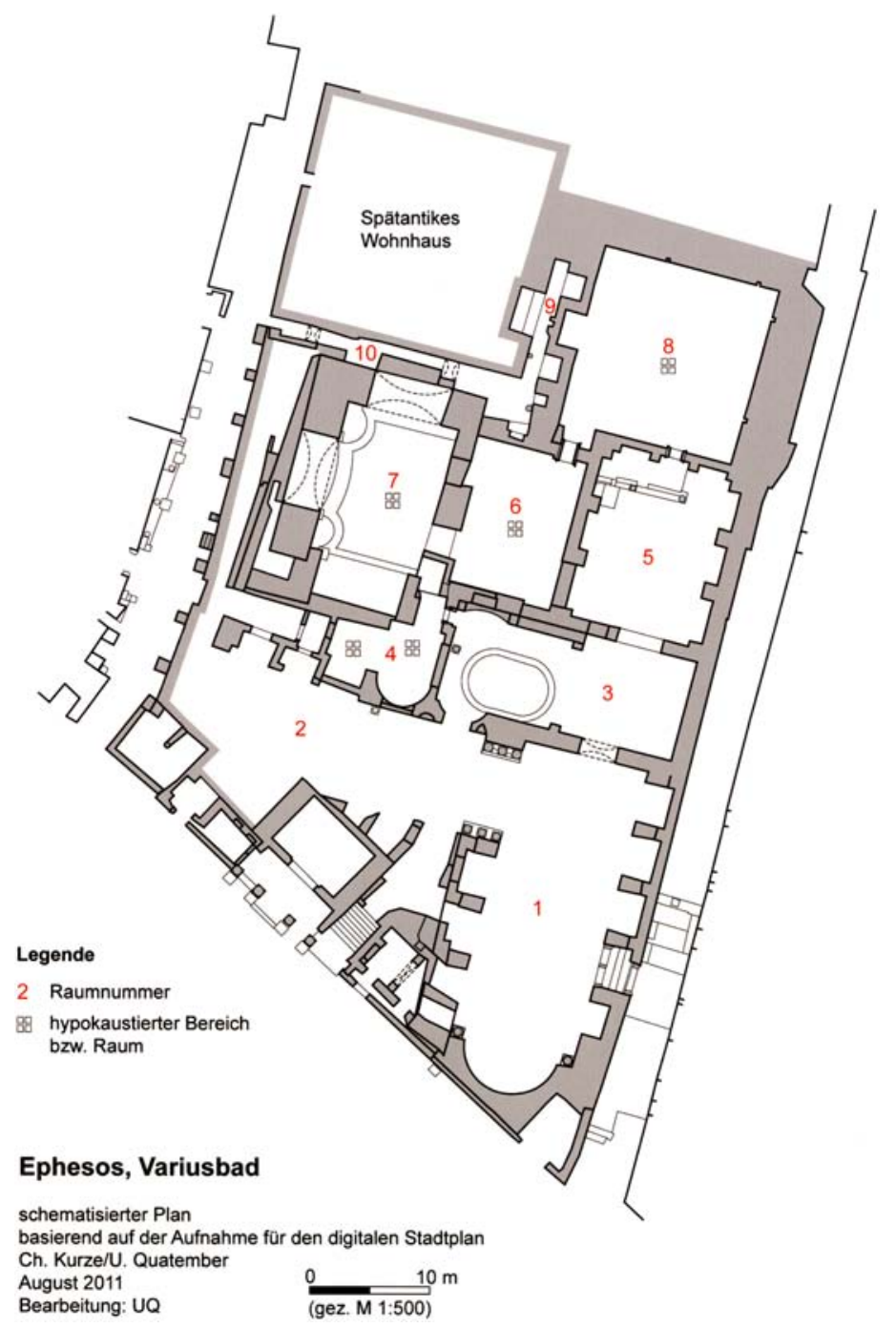

FIGURE 8 Plan of the 'Baths of Varius' and the 'temple of Hadrian'

cation indicates the moment of erection and consecration of the 'temple', that occurred between the years $114-118 \mathrm{CE}$, i.e. during the transition between the last years of reign of Trajan and the succession of Hadrian. ${ }^{124}$

the City: Impact of the Imperial Cult and the Civic Identity of Roman Ephesos." Ancient Society (46) (2016), 177 .

124 The erection of the 'temple' was decreed under the civic magistrate by the grammateus Tiberius Claudius Lucceianus, in the year 114/115 CE. The consecration, in contrast, 
Besides the façade, the pronaos presents a rich set of sculptural decorations: a single lunette relief displaying a 'Rankenfrau' is placed just above the cella's door, ${ }^{125}$ and a rectangular figurative relief is set directly underneath the architrave, on both sides of the same door. ${ }^{126}$ The rectangular relief is articulated in four panels and presents scenes from the main Ephesian mythological saga: the establishment at Ephesus of the cult of Artemis and the foundation of the city by the hero Androclus (see fig. 3). Images of emperors and personalities of the Ephesian political and civic jet set probably featured as well in the scenes displayed on the four panels. Specifically, the male figure depicted at the centre of the so-called 'Götterversammelung' - the ensemble of heroes, mythological characters and deities of local relevance displayed on the South-East relief, could be identified as Trajan. Proclaimed divus in the same period of the construction of the 'temple of Hadrian', Trajan was possibly represented on the relief in this new role, in a guise specifically alluding to his incorporation into the Ephesian pantheon and civic sphere (see fig. 4, n. 6). ${ }^{127}$ Another depiction of an emperor could be identified with the male figure wearing a cuirass and a paludamentum in the act of sacrificing to the local gods while being crowned by a Nike depicted on the North-East relief (see fig. 5). ${ }^{128}$ Again, the iconogra-

occurred during the proconsulate by Q. Servaeus Innocens, and it is dated to the year $117 / 118$ CE. See, Quatember 2018 (op. cit. note 13), 15o, with references.

125 Quatember 2018 (op. cit. note 13), 100.

126 Efes Müzesi, Selçuk, inv. 713-716. Marble. Height: 59; 61; 6o; 61 cm. Lenght: 169; 203; 194; $203 \mathrm{~cm}$. The bibliography on these reliefs is vast, see e.g. N. Saporiti, "A Frieze from the Temple of Hadrian at Ephesus." In Essays in Memory of Karl Lehmann, ed. L.F. Sandler, (New York: Marsyas Suppl. 1, 1964), 269-278; R. Fleischer, "Der Fries des Hadrianstempels in Ephesos, in: Festschrift Fritz Eichler." Jahreshefte des Österreichischen Archäologischen Institutes in Wien (1) (1967), 23-71; B. Brenk, "Die Datierung der Reliefs am Hadrianstempel in Ephesos und das Problem der tetrarchischen Skulptur des Ostens." Istanbuler Mitteilungen (18) (1968), 238-258; P. Scherrer, "Die Stadt als Festplatz: Das Beispiel der ephesischen Bauprogramme rund um die Kaiserneokorien Domitians und Hadrians." In Festrituale in der römischen Kaiserzeit, ed. J. Rüpke, (Tübingen: Mohr Siebeck, 2008), 33-62; Quatember 2018 (op. cit. note 13); Iannantuono forthcoming (op. cit. note 14).

127 The figure at the centre of the South-East relief is traditionally interpreted as Androclus accompanied by the dog. See, Brenk 1968 (op. cit. note 126), 239. For the iconography of Androclus with the dog in Ephesus, see, E. Rathmayr, "Die Präsenz des Ktistes Androklos in Ephesos." Anzeiger: Österreichische Akademie der Wissenschaften, Wien (145) (2010), 34. Recently, Ursula Quatember has argued for a different interpretation of this figure as Apollo accompanied by a deer, sacred animal of Artemis. See, Quatember 2018 (op. cit. note 13), 120, 273, D 6 and n. 1398. However, this figure could also be interpreted as a syncretic symbolisation of the triad to which the 'temple' was dedicated: Artemis, the emperor and the demos. This interpretation is more fully discussed in Iannantuono forthcoming (op. cit. note 14).

128 Efes Müzesi, Selçuk. Inv. 714. Although there are no physiognomic elements to recognize 
phy suggests the participation of this figure in the Ephesian religious-mythical realm. Most plausibly, the emperor represented in this scene was either Trajan or Hadrian - who in that same period was succeeding to the imperial seat. ${ }^{129}$ Whether or not the identification of these depictions with Trajan and Hadrian is accepted, what it is certain is that the consideration of the overall sculptural iconography and epigraphic message displayed at this site presents strong associations with Artemis, the Roman emperor and the Ephesian religious and civic pantheon.

On the basis of stylistic considerations, the four reliefs have for a long time been considered a later addition to the sculptural decoration of the building, being dated to either the Tetrarchic ${ }^{130}$ or the Theodosian age. ${ }^{131}$ However, the recent studies by the $\ddot{O} A I_{I}$ have now excluded such a late dating, and have illustrated that the whole sculptural décor has to be dated to the second century CE. ${ }^{132}$ Notwithstanding the newly established second-century CE chronology of the overall structure of the 'temple of Hadrian', it is still possible to observe multiple late-antique interventions at this site. Regardless of the pronounced connection of the 'temple' with the commemoration of non-Christian gods and heroes and (plausibly) divinised emperors, this building was maintained basically intact. The same can be observed for the rest of the monumental display at the Embolos. Despite the great transformation that the city of Ephesus underwent during Late Antiquity, the basic urban structure remained more or less unaltered. The open plazas and the orthogonal street grid which had characterised the city for so long still remained determining elements. ${ }^{133}$ Throughout the period under discussion, the Embolos remained one of the most prestigious sites of the city, and it was even upgraded to major centre of civic representa-

the officiant, the general imperial atmosphere of the scene suggests the identification of this figure with an emperor. For this interpretation, see Saporiti 1964 (op. cit. note 128), 271. For the identification of the officiant with an emperor, see also R. Bol, Amazones Volneratae. Untersuchungen zu den ephesischen Amazonenstatuen (Mainz: P. von Zabern, 1998), 133; Scherrer 2008 (op. cit. note 126), 52. Cf. Rathmayr 2010 (op. cit. note 127), 34; Quatember 2018 (op. cit. note 13), 118.

129 According to Renate Bol, although very damaged, the officiant's face seems to retain traces of an original beard, a detail that would further point to his identification with Hadrian. See, Bol 1998 (op. cit. note 127), 132. However, this detail is not confirmed by the latest analyses by Ursula Quatember. See, Quatember 2018 (op. cit. note 13), 120, 270, B 4. Cf. Iannantuono forthcoming (op. cit. note 14).

130 Brenk 1968 (op. cit. note 130).

131 Fleischer 1967 (op. cit. note 130); Scherrer 2008 (op. cit. note 126).

132 Quatember 2018 (op. cit. note 13), 54.

133 Ladstätter 2019 (op. cit. note 13), 22. 
tion of Ephesus. ${ }^{134}$ As the main site for self-presentation of the elite and of the most relevant religious, historical and civic authorities of Ephesus, the Embolos catalysed many activities of restorations and re-embellishment. Placed at this highly representative spot of the city, the 'temple of Hadrian' was recurrently involved in these activities.

Like many other buildings at Ephesus, the 'temple' was damaged by the strong earthquakes that periodically hit the city. ${ }^{135}$ In contrast to what happened to some other Ephesian temples and main public buildings, the 'temple' was each time promptly restored, at least until the late sixth century CE. ${ }^{136}$ Probably on the occasion of one of these restorations, under the rule of the first Tetrarchy, statues representing the four rulers Diocletian, Maximian, Galerius and Constantius, were erected just in front of the 'temple'. ${ }^{137}$ Later, once the memory of the tetrarch Maximian was officially condemned, the statue ded-

134 Thür 1999 (op. cit. note 28) H. Thür, "Der Embolos: Tradition und Innovation anhand seines Erscheinungsbildes." In 100 Jahre Österreichische Forschungen in Ephesos. Akten des Symposions Wien 1995, eds. H. Friesinger, F. Krinzinger (Wien: Verlag der Österreichischen Akademie der Wissenschaften, 1999), 421-428; Thür 2003 (op. cit. note 14); C. Roueché, "The Kuretenstraße: The Imperial Presence in Late Antiquity." In Neue Forschungen zur Kuretenstraße von Ephesos. Akten des Symposiums für Hilke Thür vom 13. Dezember 2006 an der Österreichischen Akademie der Wissenschaften, ed. S. Ladstätter, (Wien:Verlag der Österreichischen Akademie der Wissenschaften, 2009), 155-169; J. Auinger and M. Aurenhammer, "Ephesische Skulptur am Ende der Antike." In Byzanz—das Römerreich im Mittelalter, vol. 2, 2. Schauplätze, eds. F. Daim and J. Drauschke (Mainz: Schnell \& Steiner, 2010), 663-696.; Jacobs 2010 (op. cit. note 42).

135 See, Foss 1979 (op. cit. note 16), 76; Chuvin 1990 (op. cit. note 16), 55-56; Scherrer 1995 (op. cit. note 16), 21; F.R. Trombley, Hellenic religion and Christianization c. 370-529. 1 vol. (Leiden: Brill, 1994), 96; Bayliss 2004 (op. cit. note 23), 41; Quatember 2018 (op. cit. note 13), 146.

${ }_{13}$ For the earthquakes' damage as main reason for the decadence of the Ephesian temples in Late Antiquity, see e.g. Bayliss 2004 (op. cit. note 23), 23-25. On this phenomenon at Ephesus, see e.g. Talloen, Vercauteren 2011 (op. cit. note 13), 356.

137 For the Tetrarchic statues at the temple, see Miltner 1959 (op. cit. note 119), 267; $A E ́$ 1967, 477; $I v E$ 305; Roueché 2009 (op. cit. note 134), 158-16o; J. Auinger and M. Aurenhammer, "Ephesische Skulptur am Ende der Antike." In Ephesos in byzantinischer Zeit, eds. S. Ladstätter, F. Daim (Mainz: Verlag des Römisch-Germanischen Zentralmuseums, 2011), 175; J. Auinger and A. Sokolicek, "Ephesus." In Last Statues of Antiquity, eds. R.R.R. Smith and B. Ward-Perkins, (Oxford: Oxford University Press, 2016), 173; Quatember 2018 (op. cit. note 13), 84, pl. 3, 9, 10, 216-221. For the base dedicated to Galerius, see also LSA 720 (A. Sokolicek) with further references. For the base dedicated to Diocletian, see also LSA 718 (A. Sokolicek), with further references. For the base dedicated to Constantius, see also LSA 719 (A. Sokolicek), with further bibliography. The statue and statue base dedicated to Maximian was later removed and substituted by another statue. See infra note 118. Statues of the tetrarchs were also built at the Hydreion, see Roueché 2009 (op. cit. note 134), 157; Auinger, Sokolicek 2016 (op. cit. note 137), 172, Ladstätter 2019 (op. cit. note 13), 21. 


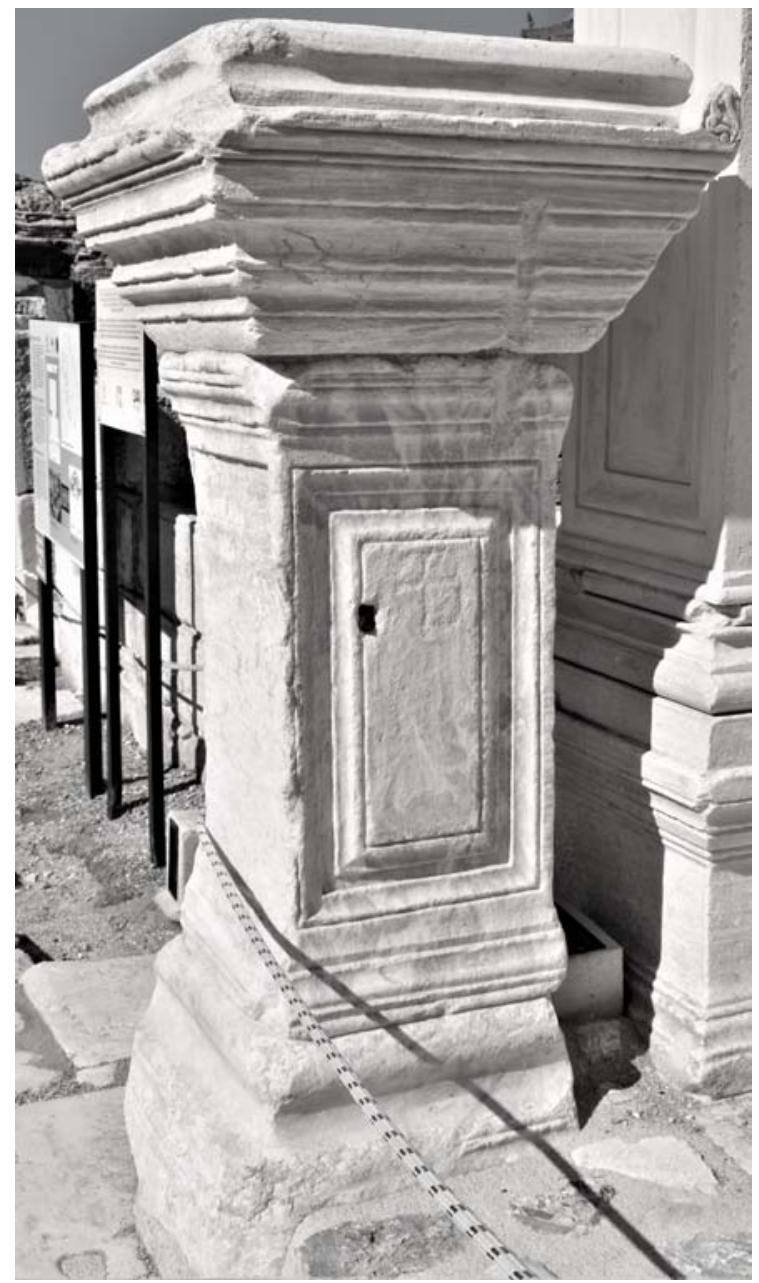

FIGURE 9

Statue base dedicated to the emperor Galerius in front of the 'temple of Hadrian' at Ephesus in the third century CE and later marked by a cross

PHOTO BY THE AUTHOR, OCTOBER 2019

icated to this Augustus was removed from display. ${ }^{138}$ At a moment that it is impossible to determine, the statue base dedicated to Galerius was marked by a cross (see fig. 9).

Another restoration of the 'temple' is attested for the late fourth century $\mathrm{CE}$, when once more a strong earthquake occurred at Ephesus and damaged the building. ${ }^{139}$ Also this time, the 'temple' was restored. Even more, on the

138 IVE 305; LSA 718; 719; 720. See also Thür 2003 (op. cit. note 13), 26o, 264 n. 12; Roueché 2009, (op. cit. note 134), 155-159.

139 In the late forth century $\mathrm{CE}$, the Western side of the pronaos collapsed and was successively repaired. See, Quatember 2018 (op. cit. note 13), 145. 
occasion the proconsul Flavius Constantinus sponsored a major plan of monumentalisation of the entire side of the Embolos directly facing the 'temple.' ${ }^{140}$ At the Eastern end of the Embolos, a new monumental arch, the aforementioned 'gate of Herakles', was erected. ${ }^{141}$ As part of the same project, a colonnade seems to have been built all along the street with the specific aim to host a new assemblage of statues. ${ }^{142}$ This statuary group was composed of as many as twelve bronze statues of Nike, which were moved here from an unknown previous location, together with their original bases. Flanked by these (recontextualised) Nikes, a bronze statue was erected in honour of the empress Aelia Flaccilla, the wife of Theodosius I. ${ }^{143}$ In the vicinity, just in front of the 'temple', a statue in honour of Flavius Theodosius, father of the emperor, was erected as a substitute for the removed monument of the Tetrarch Maximian. Another bronze statue depicting the emperor himself on horseback might have been part of the same statue group. ${ }^{144}$ The erection of a Theodosian statue group in front of the 'temple', acted as a redefining element, transforming the overall meaning of the site, and appropriating it for the contemporary imperial 'propaganda.' ${ }^{145}$

In the fifth century $\mathrm{CE}$, as attested by epigraphic evidence, the Christian Scholastica, provided a great sum of gold for reconstructing parts of the 'Baths of Varius.' ${ }^{146}$ This testimony proves that the bath complex was still in use at that time, and that it received attention from local evergetes. Moreover, the mention

140 The base was posed between the years 379 and $387 \mathrm{CE}$. See $I v E 306 ; L S A 721$, with further references. See also Quatember 2018 (op. cit. note 13), 151. For the proconsul, see PLRE 1, Dexter 3.

141 Cf. supra note 58.

142 Quatember 2018 (op. cit. note 13), 109.

143 Roueché 2002 (op. cit. note 58), 536; Auinger, Sokolicek 2016 (op. cit. note 137), 169. A contemporary use of depictions of Nike in combination with imperial commemoration is attested in the decoration of the South-East Gate of Constantinople. See e.g. P. De Staebler, "The City Wall and the Making of a Late Antique Provincial Capital." In Aphrodisias Papers 4, New Research on the City and Its Monuments. JRA Supplements 70, eds. C. Rattè and R.R.R. Smith (Portsmouth: Journal of Roman Archaeology Supplements, 2008), 298301. Statuettes of Nike were also kept in display at Sagalassos, see M. Waelkens, I. Jacobs, "Sagalassos in the Theodosian Age." In: Production and Prosperity in the Theodosian Period. Interdisciplinary studies in ancient culture and religion, ed. I. Jacobs, (Leuven: Peeters, 2014), 91-383. For the adaptation of the imagery of Nike in Late Antiquity, see Rouché 2002 (op. cit. note 58), 541-545.

144 Roueché 2002 (op. cit. note 58); Thür 2003 (op. cit. note 13); Auinger, Aurenhammer 2010 (op. cit. note 136), 684; Jacobs 2012 (op. cit. note 13), 144; Quatember 2018 (op. cit. note 13).

145 For the relocation of the statues of Nike at this site, see Roueché 2002 (op. cit. note $5^{8}$ ), 539. For the propagandistic re-use of recontextualised sculptures during Late Antiquity, see Lavan 2011 (op. cit. 59).

146 On the baths, see Yegül 1992 (op. cit. note 55), 290-291. 
of Scholastica as responsible for the financing constitutes an important attestation of the participation by Christians - and specifically Christian women -in the late-antique monumentalisation and restoration of public spaces at Ephesus. ${ }^{147}$ The Christian agency behind the restoration of the baths did not prevent the continued display at this site of symbols associated with the Ephesian 'pagan' tradition. During the archaeological investigation of the site, statuettes representing Dionysus, a river god, a satyr, and Herakles were found still in situ. ${ }^{148}$ Moreover, although displaying a plethora of 'pagan' images, the 'temple of Hadrian'-entrance hall of the complex, was left almost untouched. As aforementioned, the imagery displayed on the reliefs decorating the 'temple' and in particular on the façade and the pronaos was almost entirely focused on the representation of deities and semi-divine figures. As said, in one of the scenes displayed on the North-East relief, the emperor was probably depicted while sacrificing to 'pagan' gods. On the South-Eastern relief, most plausibly the emperor was represented as divus, and surrounded by the main Ephesian deities. Placed in a building right at the centre of the city, well visible from the street, and sacredly connoted, the reliefs could have easily triggered acts of damaging by intolerant Christian groups. Instead, only a few changes were made. Specifically, the sexual attributes of some of the represented figures were chiseled away. ${ }^{149}$ As seen in similar cases of erasure of genitalia attested at different sites at Ephesus and Aphrodisias, these alterations did not compromise the preservation of the overall sculptural décor.

\section{Remembering the Theodosian Dynasty at the 'Temple of Hadrian'}

The choice to turn the 'temple of Hadrian' into a site for the representation of the current imperial household may well have been aided by the original function of the building, namely the commemoration of Hadrian and possibly of Trajan as participants of the Ephesian context.

Under Theodosius, the memorialisation and appropriation of the figure of Trajan gained momentum in the shaping of narratives about contemporary cultural renewal of the imperial household and of society at large. ${ }^{150}$ Famously,

\footnotetext{
147 G.M. Rogers, "The Constructions of Women at Ephesos." Zeitschrift für Papyrologie und Epigraphik (9o) (1992), 223.

148 Aurenhammer 1990 (op. cit. note 55), nos. 38, 49, 83, 94; Jacobs 2010 (op. cit. note 42), 293, n. 3 .

149 Quatember 2018 (op. cit. note 13), 270-273.

150 For the emergence of the figure of Trajan as a model for emperorship in the Theodosian
} 
at this time, the imperial 'propaganda' tended to represent Trajan as a direct ancestor of Theodosius I. ${ }^{151}$ Designed to praise the emperor, Pacatus' panegyric proposed a eulogy to Spain, motherland of Trajan, Hadrian and Theodosius I:

It is she that spawns the toughest soldiers, the most experienced generals, the most eloquent orators, the most famous poets; she is the mother of judges-and the mother of Emperors. She gave the Empire the great Trajan, and then Hadrian; to her the Empire is indebted for you. Let the land of Crete, famous as the cradle of the child Jupiter, and Delos, where the divine twins learnt to crawl, and Thebes, illustrious as the nursemaid of Hercules, yield to this land. We do not know whether to credit the stories we have heard, but Spain has given us a god whom we can actually see. ${ }^{152}$

This passage explains the importance of the Trajanic and Hadrianic legacy in the presentation of the emperor Theodosius I. This alleged ancestry was not confined to literary texts of praise. Many urbanistic choices adopted to express the grandeur of Theodosius I and of the other members of his family seem to reflect a similar interest in associating Trajan and Hadrian with the new imperial dynasty. The Forum Theodosii at Constantinople, for instance, echoed that of Trajan in Rome. Like the forum of Trajan, that of Theodosius featured a columna cochlis, a large basilica, and imperial equestrian statues. Moreover, the forum of Theodosius presented iconographic references to Herakles, Trajan's patron deity. ${ }^{153}$ At Ephesus, the aforementioned 'gate of Herakles' was part of

age, see O. Hekster, S. Betjes, S. Heijnen, D. Jussen, K. Iannantuono, E. Manders and D. Syrbe, "The fame of Trajan: a late-antique invention", in preparation.

151 See e.g. Orosius, Historiae adversus paganos 7, 34, 2-4; Epitome de Caesaribus 48, 1; 6 Claudian, IV. cons. 18-20; 315-320; Themistius, Oratio 19, $219 \mathrm{c}$.

152 Pan. Lat. II (12), 4, 5 .

153 See e.g. R.H.W. Stichel, “Kaiser Theodosius I. 'Melior Traiano'—Ein Deutungsversuch zur Ausstattung des Forum Tauri in Konstantinopel (mit einem Exkurs zum Zerstörungsdatum der Theodosius-Säule)." In Zurück zum Gegenstand. Festschrift für Andreas E. Furtwängler, vol. 2, eds. R. Einicke, S. Lehmann, H. Löhr, G. Mehnert, A. Mehnert, A. Slawisch, (Langenweißbach: Beier \& Beran, 2009), 155-156. Even more than that of Theodosius, the colossal column of Arcadius took inspiration by that of Trajan in Rome and similarly functioned as imperial mausoleum. See, J. Matthews, "Viewing the Column of Arcadius at Constantinople”. In Shifting Cultural Frontiers in Late Antiquity, eds. D. Brakke, D. Deliyannis and E. Watts (Farnham: Ashgate Publishing, 2012), 211-223. Moreover, several byzantine literary accounts make reference to a now lost statue group featuring bronze likenesses of several members of the Theodosian imperial family and of Trajan and Hadrian. The mention of statues of Trajan and Hadrian as part of this group could be the result of a misunderstanding of likenesses of the Theodosian lineage with those of earlier emperors. 
the program of renewals launched at the Embolos during the Theodosian age. These references to Herakles in Theodosian sculpture and architecture further confirm that images taken from traditional 'pagan' mythology and religion were still largely used in monumental art meant to praise the imperial household, even under the reign of a declared Christian like Theodosius I. ${ }^{154}$

For some groups, the choice to appropriate 'pagan' themes and to incorporate them into the imperial communication was hard to digest. The attempt to recontextualise the twelve Nikes on the Embolos, for example, was not appreciated by all layers of society. Commenting on the new statuary display at the 'temple of Hadrian', the bishop Eusebius described the project as directed to the mocking of the older 'pagan' statues relocated at the site. ${ }^{155}$ In reality, it is very unlikely that statues placed in a highly relevant site of the city, purposefully redesigned to host likenesses of members of the current imperial court, were set in this new context to be ridiculed. ${ }^{156}$ Instead, their display suggests marked honorific purposes and the will to integrate images taken from the nonChristian Ephesian tradition into the new imperial narrative. Rather than a generalised Christian prejudice against 'pagan' statues, Eusebius' perspective attests to the persistence of tensions and of different positions regarding the management of such a controversial 'heritage' in the multifaceted late-antique society. ${ }^{157}$ Moreover, Eusebius' opinion has to be interpreted in light of his posi-

Nevertheless, these sources attest the topos of a connection between the Theodosian family and Trajan and Hadrian. Parastaseis 18, 35; Patria II, 37, 40, 104. For this statue group, see LSA 2713; 2714; 2715, with relative discussions. Cf. L. Lavan, Public Space in the Late Antique City, volume 1 (Leiden-Boston: Brill, 2020), Appendix 1, 55 o.

154 For the survival of mythological themes in late-antique sculpture, see e.g. N. Hannestad, "Late Antique Mythological Sculpture-In Search of a Chronology." In Statuen in der Spätantike, eds. F.A. Bauer and C. Witschel (Wiesbaden: Reichert Verlag Wiesbaden, 2007), 273-305.

155 Eusebius, Vita Constantinii 3,54. Cf. Trombley 1994 (op. cit. note 16), 112-114; Saradi 2008 (op. cit. note 29), 114 .

156 C. Lepelley, "Le musée des statues divines. La volonté de sauvegarder le patrimoine artistique païen à l'époque théodosienne." Cahiers archéologiques (42) (1992), 10; Jacobs 2010 (op. cit. note 42), 289 .

157 In the Theodosian age, the meaning of the image of Victory underwent a significant mutation. Already in the mid-fourth century CE, the removal of the altar of Victory from the Senate House in Rome provoked a long-lasting and fierce debate between conservative and Christian intellectuals. See, Symmachus, Rel. 3; Ambrose, Ep. 17-18. Cf. Roueché 2002 (op. cit. note 58), 541-545 with references. On the other hand, images of Victory continued to be displayed on late-antique monuments and coinage as part of the imperial representation, and eventually even became a major theme of the early Christian iconographic repertoire. See e.g. M.R. Alföldi, "Signum Deae: Die kaiserzeitlichen Vorganger des Reichsapfels." Jahrbuch für Numismatik und Geldgeschichte (15) (1961), 33. 
tion of foreigner, and as such as that of a non-Ephesian Christian intellectual comprehensibly less attached to the historical 'heritage' of Ephesus and more concerned by the 'pagan' connotation of reused statues.

Opting for the erection of imperial statues at the 'temple of Hadrian', on the other hand, did not necessarily mean choosing a 'pagan' site as a space to commemorate the Theodosian dynasty. During Late Antiquity, the structure of the 'temple' was probably preserved also by virtue of its disengagement from non-Christian rituals. There is in fact no conclusive evidence that points to the endurance of the building as a space connected to religious performances in the early-fifth century CE. ${ }^{158}$ Instead, the continued use of the 'Baths of Varius', restored by the devote Christian Scholastica, seems to indicate that the 'temple' continued to function as a monumentalised entrance of the thermal complex. Having lost its meaning of 'pagan' site, the 'temple' plausibly continued to be preserved, restored and refurbished by virtue of its highly representative placement in the city, its connection to the baths, and its relatively good state of conservation. The 'temple' was then considered as a site of significance for the history of Ephesus and for its urban decorum rather than as a 'pagan' 'temple'. During Late Antiquity, the building was included into a more general process of redefinition of the sculptural décor displayed at the Embolos aimed at making this entire part of the city more acceptable to the multifaceted Ephesian community.

The lack of transformation of some of the images displaying gods and heroes at the 'temple' can be explained by interventions that occurred at other surrounding sites. This is the case of the figure of Androclus, prominently featuring the reliefs decorating the 'temple' (see fig. 3). As aforementioned, the heroon of Androclus, a building placed in the vicinity of the 'temple', was visibly modified by the carving of some large crosses on the slabs enclosing the external side of the building facing the Embolos (see fig. 7). In this way, the site and maybe even the figure of Androclus himself were desensitised and somehow integrated into a Christian narrative. Similarly, the statue base dedicated to Galerius, emperor famous for having actively pursued persecutions of Christians, was marked by an apotropaic Christian symbol (see fig. 9). The erasure of the sexual parts of the figure represented on the relief decorating the 'temple', on the other hand, can be better explained when considered in light of the function of the building as the entrance hall of a bath complex. During Late Antiquity, fountains and public baths were public spaces still worthy of being frequented notwithstanding their problematic decorations typically crowded

$15^{8}$ Cf. supra note 4. 
with 'pagan' subjects. At Ephesus like at other cities of the Empire, in many cases statues and sculptural decorations displayed at such sites were targeted by acts of transformation. The erasure of the most troublesome elements, in a fashion similar to that previously observed for the nymphaeum Traiani, the fountain of Pollio, and the fountain nearby the stadium, the 'Straßenbrunnen' is one of the most commonly attested practices. ${ }^{159} \mathrm{At}$ all these sites and at the 'temple of Hadrian', images of non-Christian deities and semi-divine characters were not destroyed but instead they were adapted to become worthy of conservation as 'heritage'. 160

Reclaiming Monuments in Late-Antique Ephesus and Today

The case of the 'temple of Hadrian' shows how, in the changed context of lateantique Ephesus, vandalism and destruction were not the only possible ways to manage potentially disruptive monuments. Even when targeted, only rarely were monuments severely damaged, and only at times did damage result in definitive removals. Instead, more nuanced strategies like selective erasures of problematic parts, relocations, or erections of counter-monuments were often systematically applied. These last examples can be interpreted as efforts of preservation and recontextualisation.

The 'temple of Hadrian' was a site of major importance for many Ephesians, a repository of the city's collective memory. As such, the 'temple' was beautified by images of deities, mythological heroes and historical personalities of local importance. Images of Roman emperors were staged in between 'pagan' gods and local figures to be shown in the act of participating in the Ephesian religious-mythical and civic dimension. If not by the reliefs, this narrative was certainly conveyed by the dedicatory inscription, jointly addressing Artemis, the emperor and the demos. Altogether, the visual and verbal messages presented at the 'temple' highlighted the high status of Ephesus in the broader context of the Empire. Over time, the changes in the common perception of traditional art and the transformations of the display at the 'temple' determined a progressive shift of the entire site significance. Notwithstanding the images of traditional deities and heroes that were still displayed at the

159 N. Hannestad, "Castration in the Baths." In Macellum. Culinaria Archaeologica. Robert Fleischer zum 6o. Geburtstag von Kollegen, Freunden und Schülern, eds. N. Birkle, I. Domes, S. Fähndrich, A. Nießner, T. Reiß and A. Zschätzsch (Mainz: Archäologisches Institut, 2001), 66-77.

16o Lepelley 1992 (op. cit. note 156), 10-12. 
'temple', plausibly the site ceased to be considered 'pagan'. Instead, it continued to act as a major civic landmark. Thus, its monumental apparatus underwent re-negotiations that entailed some removals but, at the same time, the 'temple' was substantially preserved intact. The statue representing Maximian was taken away off display after his damnatio memoriae, while the genitalia of the deities and heroes sculpted on the reliefs were chiseled off once they had become disturbing. On the other hand, the building was periodically recontextualised by the addition of new icons and related messages, such as the gallery of old and new statues placed at the site during the Theodosian era. In this way, not only the 'temple' was further monumentalised, but also the long history of the city memorialised by the small building on the Embolos was updated. Ultimately, during the Theodosian age, the 'temple' was appropriated for new representative purposes. The new narrative displayed at the 'temple' staged the commemoration of the Theodosian dynasty within a setting of local historical importance that reconfirmed the status of Ephesus as a city granted imperial favour.

The examination of the later fate of the 'temple of Hadrian' has offered a better understanding of the practices adopted for the management of monuments in late-antique Asia Minor. Moreover, this analysis provides a distantiated perspective on contemporary phenomena of contestations against statues and monuments with which I opened this article.

Through the case of the 'temple of Hadrian', this article has illustrated how the various forms of dissent against images attested in Late Antiquity cannot be collectively dismissed as mere acts of vandalism generated by different versions of 'iconoclasm'. The same observation is applicable to today contestations. ${ }^{161}$ In both cases, agencies and motivations behind such acts of protest need to be carefully considered. ${ }^{162}$ However, some general trends seem recognisable. Scholarly research focusing both on past and present phenomena, for instance, has highlighted how acts of removal can be described as powerfully symbolic (see fig. 10). ${ }^{163}$ In antiquity as well as today, pulling down and removing pub-

161 Marshall 2017 (op. cit. note 1), 104; Bauer 2020 (op. cit. note 1), 2-4.

162 Cf. Ö. Harmanşah, "Isıs, Heritage, and the Spectacles of Destruction in the Global Media." Near Eastern Archaeology (78) (3) (2015), 170-177; F.B. Flood, "Idol-Breaking as ImageMaking in the 'Islamic State'." Religion and Society: Advances in Research (7) (2016), 116-138, for a reflection about the IsIs's program of destruction of cultural heritage in Syria and Iraq.

163 See e.g. J. Elsner, "Iconoclasm and the Preservation of Memory." In Monuments and Memory. Made and Unmade, eds. R.S. Nelson and M. Olin (Chicago: University of Chicago Press 2003), 209-232; F. Rambelli, E. Reinders, "What does iconoclasm create? What does preservation destroy?" In Iconoclasm: Contested Objects, Contested Terms, ed. S. Boldrick, R. Clay 


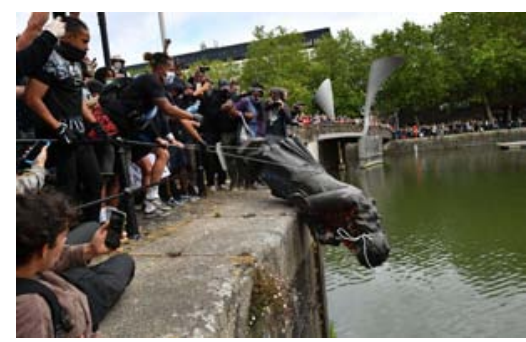

FIGURE 10

Protesters toppling down the statue of Edward Colston at Bristol, June 8th 2020

(C) WIKIMEDIA COMMONS

lic monuments can operate as a marker of disempowerment. ${ }^{164}$ On the other hand, removals do not necessarily kill memories. Remembrance may succeed despite the removal of material memorials. For instance, the elimination of the likeness of the tetrarch Maximian at the 'temple of Hadrian' did not result in the forgetting of this emperor, at least for some considerable time. On the contrary, the elimination of Maximian's statue most plausibly reminded most viewers of the circumstance of his damnatio memoriae. In other words, the removal of the monument created a notable absence, a significant void that viewers familiar with the previous display would reasonably have filled with memories of Maximian's disgrace. ${ }^{165}$

(London: Ashgate, 2007), 15-33; J. Elsner, "Iconoclasm as Discourse: From Antiquity to Byzantium." The Art Bulletin (94) (3) (2012), 368-394; S. Sande, "Conclusions: Iconoclasm in History and Present-day Use of Images.", In Iconoclasm from Antiquity to Modernity, eds. M. Prusac and K. Kolrud (Burlington: Ashgate 2014), 17-188; G. de Bruyn, "Briser les idoles païennes ou les sauvegarder? Le sort des statues divines de Caesarea (Cherchel, Algérie) à la fin de l'Antiquité." Revue Historique (677) (2016), 3-25. For modern perspectives on similar phenomena, see e.g. D. Gambioni, The Destruction of Art. Iconoclasm and Vandalism since the French Revolution (London-New Heaven: Yale University Press, 1997), 333-335; B. Latour, "What is iconoclash? Or is there a world beyond the image wars?" In Iconoclash: Beyond the Image Wars in Science, Religion, and Art, eds. B. Latour and P. Weibel (Cambridge: MIT Press, 2002), 11. For the notion of "repressive erasure" and its role in processes of oppression, see P. Connerton, "Seven types of forgetting." Memory Studies (1) (1) (2008), 6 o.

164 Burch Brown 2017 (op. cit. note 1), 67-71; Burch-Brown 2020 (op. cit. note 2), 7-9; Frank, Ristic 2020 (op. cit. note 1), 555; Timmerman 2020 (op. cit. note 1). For the notion of 'prescriptive forgetting' and its role of empowerment of groups sustaining different ideologies and interests from those represented by the contested monuments, see Connerton 2008 (op. cit. 163), 62-64. For a similar perspective, cf. Frowe 2019 (op. cit. note 1); Schulz 2019 (op. cit. note 1), 183-186; Burch-Brown 2020 (op. cit. note 2), 7; Dickinson 2020 (op. cit. note 1); Frank, Ristic 2020 (op. cit. note 1), 554.

165 Charles Hedrick describes removals of monuments as "significant silences and erasures". See, C.W.J. Hedrick, History and Silence: Purge and Rehabilitation of Memory in Late Antiquity (Austin: University of Texas Press, 200o), 117 (emphasis in the original quote). Simi- 
This case explains how actions of removal can act as producers of alternative forms of commemoration-a process that could help to loosen the ties between remembering and honouring. ${ }^{166}$ In different contexts, removals can be insufficient for changing the narrative, however. The erasure of the statue of Maximian was operated under specific conditions that made this removal particularly 'visible' and therefore significant. As seen, the statue of Maximian was originally set within a group of three other monuments dedicated to his colleagues Diocletian, Galerius and Constantius. Whereas Maximian's statue was removed, the other three ones were left standing in situ somehow reinforcing the void created by the statue's deliberate removal and making it representative of the counter-discourse on condemnation. In the past and today, in situations where removals are conducted in a less noticeable manner, outcomes can differ. For instance, removing monuments could initiate phenomena of indifference, and denial. ${ }^{167}$

Preservation mostly fits in the most widely accepted practices of 'cultural heritage' protection. ${ }^{168}$ Commonly, preservationists advocate that this option has the advantage of creating more inclusive memoryscapes. ${ }^{169}$ Yet, the choice to preserve contested monuments can hold some inherent risks. ${ }^{170}$ Memory studies have in fact proven how the creation of memory and of commemorative monuments is always selective. ${ }^{171}$ Moreover, scholarly research has high-

larly, Caroline Vout describes the practices of removal and/or destruction of the emperors' images resulting from their damnatio memoriae in these terms: "absences arguably speak the loudest". See, C. Vout, "The Art of 'Damnatio Memoriae." In Un Discours en images de la condamnation de mémoire, ed. S. Benoist (Metz: Centre Régional Universitaire Lorrain d'Histoire, 2008), 165. For the notion of damnatio memoriae as creatio memoriae, see also A. Omissi, "Damnatio Memoriae or Creatio Memoriae? Memory Sanctions as Creative Processes in the Fourth Century AD." The Cambridge Classical Journal (62) (2016), 195-196. Cf. supra note 6.

$166 \operatorname{Lim} 2020$ (op. cit. note 1), 193.

167 Demetriou, Wingo 2018 (op. cit. note 1), 348.

168 Ashworth, "Conservation as Preservation or as Heritage: Two Paradigms and Two Answers.", Built Environment (23) (2) (1997), 92-95.

169 Mary Beard, for example, has repeatedly supported preservationism against the Rhodes Must Fall campaign. See M. Beard, "Cecil Rhodes and Oriel College Oxford." The Times Literary Supplement, December 20, 2015; Beard 2020 (op. cit. note 1). Similar considerations about the advantages of preserving were enunciated by the philosopher Theodor W. Adorno. See T.W. Adorno, "The meaning of working through the past." In Critical Models: Interventions and Catchwords, ed. T.W. Adorno, (New York: Columbia University Press, 1998), 89-103. For a discussion about the advantages of the preservation of contested monuments, see also Burch-Brown 2020 (op. cit. note 2), 5 ;

170 Burch-Brown 2020 (op. cit. note 2), 4-7.

171 For the selective process at the base of the creation of memory see e.g. E. Hobsbawm, 
lighted that the meaning attached to the object reifying historical records and considered as 'heritage' is not static but always in flux. ${ }^{172}$ The analysis of the management of the monumental display at the 'temple of Hadrian' indicates that processes of appropriation can occur within the context of monumental preservation. Dedicated to the commemoration of Artemis, Trajan and Hadrian and the civic community of Ephesus in the second century $\mathrm{CE}$, the 'temple of Hadrian' was later appropriated for the glorification of the Tetrarchs first and of the Theodosian dynasty later. Moreover, the commemoration of polytheistic deities, once central at this site, progressively faded and eventually became irrelevant. At that point, icons once symbolising the traditional Ephesian religious-mythical dimension could enter into a new discourse.

Actions directed at recontextualisation, for example through the practice of musealisation, are also often proposed as preferred approaches to deal with contested monuments. ${ }^{173}$ Practically, the recontextualisation of contested monuments could aid the disconnection of these objects from their original position of honour. ${ }^{174}$ In the case of contemporary musealisations, the setting of contested objects in displays aptly dedicated to the explanation of their complex biography could be an example of a potentially successful approach. Recontextualisations are not always effective in this sense, however. ${ }^{175}$ In the case of modern musealisations, for instance, recontextualisations can entail the risk of diminish street-level familiarity with monuments. ${ }^{176}$ As a result, the musealisation of tainted memorabilia can represent the silence of disturbing memories. ${ }^{177}$ In the case of the 'temple of Hadrian', the recontextu-

"Introduction. Inventing Traditions." In The Invention of Tradition, eds. E. Hobsbawm and T. Ranger (Cambridge: Cambridge University Press, 1983), 1; P. Connerton, How Societies Remember (Cambridge: Cambridge University Press, 1989 [1992]), 3; Nora 1989 (op. cit. note 78); D. Lowenthal, "History and Memory." The Public Historian (19) (2) (1997), 31; E. Said, "Invention, Memory, and Place." Critical Inquiry (26) (2) (200o), 179.

172 For the creation of heritage as process of commodification, see e.g. A. Appadurai, The Social Life of Things: Commodities in Cultural Perspective (Cambridge: Cambridge University Press, 1986); D. Harvey, "Heritage Pasts and Heritage Presents: temporality, meaning and the scope of heritage studies." International Journal of Heritage Studies (7) (4) (2001), 319-338. For the use of 'heritage' in contemporary political discourses, see e.g. Y. Hamilakis and E. Yalouri, "Sacralising the past: the cults of archaeology in modern Greece." Archaeological Dialogues (6) (2) (1999), 115-135. Cf. supra notes 2 and 4.

173 E.g. Frowe 2019 (op. cit. note 1); Baxter 2020 (op. cit. note 1). For the general perception of this position, see Burch-Brown 2020 (op. cit. note 2), 3.

174 Schulz 2019 (op. cit. note 1), 178; Lim 2020 (op. cit. note 1), 195.

175 Kreps 2020, 107.

176 Burch-Brown 2020 (op. cit. note 2), 10.

177 Auslander 2018 (op. cit. note 1), 138. In the year 1953, under the commission of the French 
alisation of the statues of Nike at the 'temple' partially changed the meaning of these statues and it was useful to reinforce the honourific commemoration of the Theodosian dynasty. Similarly, the dedication of the Tetrarchic and Theodosian monuments in front of the 'temple of Hadrian' - a practice that could be described as counter-monumentality, eventually resulted in the transformation of the overall commemorative purposes of the site. ${ }^{178}$ As seen for these examples, acts of recontextualisation can add further layers of significance, redefining and/or subverting meanings previously attached to monuments.

By transforming the original sense of monuments, actions directed either to removal, preservation or recontextualisation can all result in attempts of appropriation. Clearly, processes of cultural appropriation are not to be condemned per se. In fact, recontextualisations can successfully subvert narratives nowadays perceived as hideous, shifting the attention towards previously marginalised historical events and disempowered groups (see fig. 11). ${ }^{179}$ As demonstrated by the anthropologist and geographer David Harvey, and by the philosopher and sociologist Henri Lefebvre before him, exercising the 'right of the city' entails the possibility of changing, collectively, what it is publicly commemorated. ${ }^{180}$ Choosing practices to manage our monumental landscapes more consciously and allowing larger participation in the process can be part of an important process of unpacking troublesome historical situations. ${ }^{181} \mathrm{Sim}-$ ilar processes could lead to the construction of new, more inclusive, collective memories. ${ }^{182}$

publisher and academic journal Présence Africaine, Chris Marker and Alain Resnais directed a short film about the commodification of African art in European museums called: Les Statues meurent aussi (The Statues Also Die).

${ }_{17} 8$ As for contemporary practices, most often, recontextualisations are operated via insufficiently significant means, however. The creation of explanatory plaques in the vicinity of contested monuments is an example of recurrently adopted forms of inadequate and therefore often unsuccessful recontextualisation. Because of their limited scale, plaques are rarely noticeable and frequently ignored by the majority of viewers. Consequently, the overall perception of monuments recontextualised in this way often rests unchanged. A frequent outcome of uncompromising preservation and failed recontextualisation is the triggering of uncontrolled actions of dissent against contested statues and memorials. See, Frank, Ristic 2020 (op. cit. note 1), 553; Lai 2019 (op. cit. note 1), 613-614.

179 Lai 2019 (op. cit. note 1), 6og; Burch-Brown 2020 (op. cit. note 2), 12-13.

180 H. Lefebvre, Le droit à la ville (Paris: Edition Antropos, 1968); D. Harvey, "The right of the city." In Social Justice and the city (revised edition), ed. D. Harvey (Athens: University of Georgia Press, 2009), 315-331.

181 Harvey 2009 (op. cit. note 180), 315 .

182 Apaydin 2020 (op. cit. note 1), 95 . 


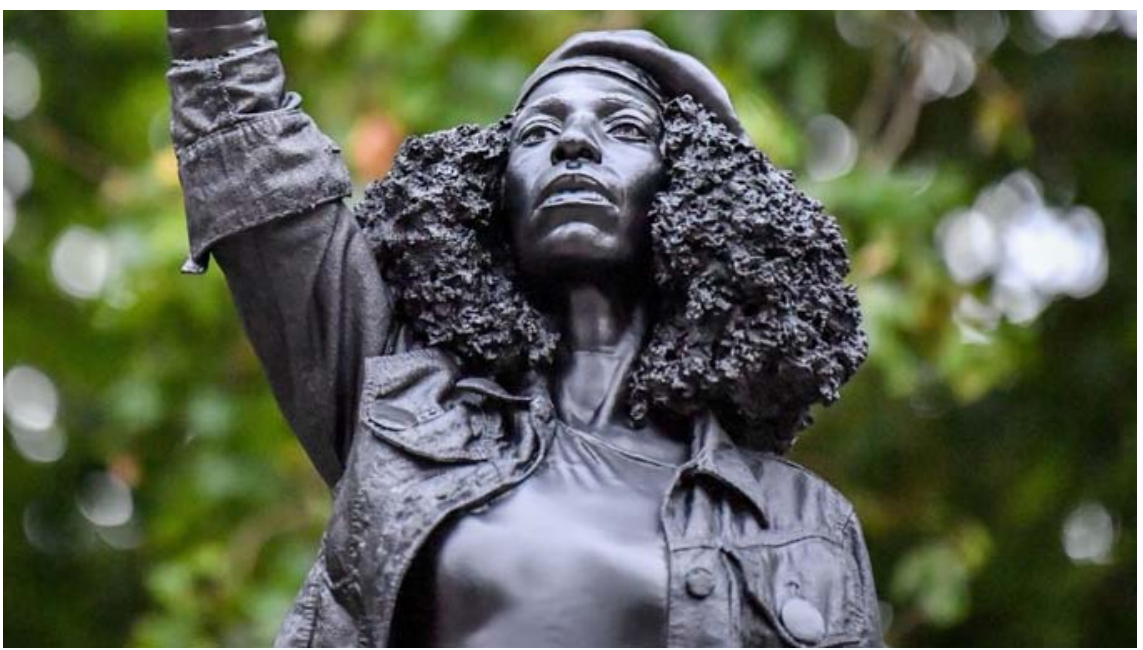

FIGURE 11 Counter-monument erected in the vicinity of the statue of Edward Colston at Bristol, June 14th 2020

(C) WIKIMEDIA COMMONS

In conclusion, focusing on the late-antique phase of the 'temple of Hadrian' at Ephesus, this article has investigated different approaches to manage potentially troublesome monuments. The analysis of the late-antique transformations occurred at this 'temple' has helped to illustrate that preserving, removing, and recontextualising monuments can all determine forms of cultural appropriation. Highlighting cultural appropriation as a possible outcome of these approaches can create useful awareness in the administration of contemporary monumental landscapes.

\section{Acknowledgments}

This research is part of the Nwo-funded project 'Constraints and Traditions. Roman Power in Changing Societies' (https://www.ru.nl/rich/our-research/res earch-groups/the-ancient-world/current-projects/projects/project-constraint s-tradition/). The author is grateful to Olivier Hekster, Nathalie de Haan, Stephan Mols, Daniëlle Slootjes, Laura Nasrallah, Paula Kalkman and Mirte Liebregts for their comments on earlier drafts, to Bettina Schwarz for providing relevant images, and to Claire Stocks for the language editing, and to the anonymous reviewers of the Journal of Applied History for their keen revisions. 